\title{
Identificação partidária e voto. As diferenças entre petistas e peessedebistas
}

\author{
Bruno Wilhelm Speck \\ Elizabeth Balbachevsky
}

\section{Introdução ${ }^{1}$}

A identificação partidária é uma construção abstrata que capta um sentimento de proximidade dos cidadãos para com um partido político. O conceito surge no contexto da tentativa de explicar o comportamento eleitoral dos cidadãos. O argumento principal da literatura internacional e nacional supõe que a identificação com um partido político afeta a escolha eleitoral porque limita as opções "aceitáveis" na perspectiva do eleitor. Na literatura clássica, a identificação partidária apresenta quatro características importantes: ela é adquirida no processo da socialização política, é afetiva e rotinizada, mais do que racional, e apresenta estabilidade no tempo. Por isso, ela serve de bússola para diferentes aspectos do comportamento e das avaliações feitas pelos cidadãos com relação ao processo político. Por esse motivo, a literatura internacional usa o mapeamento da identificação partidária como uma das grandes chaves para entender as relações entre eleitores e partidos políticos.

A proposta de explicar o comportamento eleitoral por meio da identificação partidária disputa e compartilha espaço com outras escolas sobre o comportamento eleitoral. O conceito da identidade partidária está em consonância com a escola da cultura política, que também diferencia as dimensões psicológica e subjetiva para entender o complexo sistema de valores que organiza o relacionamento do cidadão com o mundo político. Nessa abordagem, a socialização política e a regularidade de expressão dos padrões interiorizados, através da reiterada participação eleitoral, têm um papel importante para explicar a estabilidade dos padrões agregados de votação num país. Para essa literatura, ao votar, o eleitor expressa uma identidade com o mundo da política. Essa identidade é estável e orienta as escolhas do eleitor a cada votação. Realinhamentos eleitorais importantes são antes explicados pela mobilização de novos contingentes da população para a arena eleitoral e menos pelo resultado da conversão de antigos eleitores (Almond e Verba, 1965; Andersen, 1979).

\footnotetext{
1 Este artigo é resultado do projeto temático "Organização e funcionamento da política representativa do estado de São Paulo (1994 e 2014)", desenvolvido por professores da UFSCar, Unicamp e USP, com financiamento da Fapesp (projeto n.2012/19330-8).
} 
Outra escola de explicação do voto é a sociologia política, que, na clássica versão de Lipset e Rokkan (1967), entende os padrões de comportamento eleitoral a partir da cristalização das clivagens sociais que marcaram as sociedades no momento decisivo da formação nacional e da fundação dos partidos políticos. Num certo sentido, para essa escola, essas clivagens foram congeladas em relações de representação e clientelismo entre partidos e grupos sociais. Assim, somente o advento da mobilidade social acelerada pode dissolver esses mileus. Nesse sentido, os modelos produzidos pelas abordagens da cultura política e da sociologia política são mais complementos do que concorrentes do conceito da identidade partidária. Ambas exploram aspectos mais perenes dessa relação entre partidos e eleitorado, complementando a abordagem psicossocial com fatores estruturais e trajetória histórica.

A escola da escolha racional tem uma relação mais conflituosa com o conceito da identidade partidária (Downs, 1957). Na sua vertente sobre o voto econômico, essa escola argumenta que a escolha do eleitor expressa uma avaliação racional das propostas futuras, e, principalmente, do desempenho passado dos governos. Para essa abordagem, a relação entre eleitor e os partidos tem origem em uma avaliação racional da relação entre os seus interesses e os resultados alcançados pelo partido quando no governo, bem como com as suas propostas futuras. Assim, essa relação não é fruto de uma identidade irrefletida. Para essa escola, a avaliação que o eleitor faz do desempenho do governo seria o fator decisivo a orientar o seu voto. A satisfação se expressaria no apoio ao partido do governo, e a insatisfação, no voto de oposição, alimentando realinhamentos partidários importantes. Reis (1988) explorou a tensão entre as duas abordagens em um artigo importante para a literatura brasileira. Por outro lado, a literatura internacional também registra movimentos relevantes no sentido de fechar a distância entre essas duas visões. Fiorina (1977) tentou reconciliar as duas óticas em sua teoria sobre o comportamento eleitoral. Para esse autor, a escolha racional praticada durante várias eleições pode levar à rotinização e à fidelização. A análise do histórico do voto econômico pode criar padrões de fidelidade com um partido muito similares à concepção expressa pelo conceito de identidade partidária. No entanto, nesse modelo, os processos de rotinização e interiorização não têm a estabilidade suposta no modelo psicossocial. Eles não resistiriam a mudanças mais profundas na avaliação do desempenho de governos e, portanto, essas revisões, quando generalizadas na população, estariam na raiz de importantes realinhamentos eleitorais.

Mesmo que o lugar da identificação partidária nas escolas sobre o comportamento eleitoral tenha passado por transformações, o conceito permanece como uma referência importante na ciência política (Dalton, McAllister e Wattenberg, 2003). Um dos motivos práticos é que perguntas sobre a identificação partidária são incluídas nas pesquisas de opinião política desde as primeiras sondagens conduzidas pela Escola de Michigan nos anos 1960 (Campbell et al., 1960). Desde então, legiões de cientistas políticos se dedicaram a analisar o partidarismo a partir desses dados. Nesse artigo 
faremos uma breve retrospectiva de trabalhos sobre a identificação partidária no Brasil, para em seguida analisar o significado da identificação partidária nas eleições de 2014, a partir dos dados coletados na pesquisa Eseb 2014. A revisão da literatura cobre quatro grupos temáticos: análises descritivas que exploram o perfil social, regional ou demográfico dos eleitores que expressam identidade partidária no Brasil; os trabalhos sobre o impacto do partidarismo sobre o comportamento político dos cidadãos; investigações sobre a origem e as causas da identificação partidária; e trabalhos que questionam a validade do conceito e de sua operacionalização nas pesquisas.

$\mathrm{Na}$ literatura internacional, a identidade partidária foi também usada para entender as dinâmicas de competição eleitoral nas novas democracias que se formaram e consolidaram desde os anos 1980 (Barnes, McDonough e Pina, 1985). No caso do Brasil, as pesquisas eleitorais nos anos 1970 encontraram altas taxas de identificação dos eleitores com as duas opções partidárias permitidas pela ditadura militar. A identificação com a Arena ou o MDB permitiu avaliar o perfil regional e social dos eleitores inclinados a apoiar o regime ou o partido de oposição (Lamounier, 1980). Assim, a literatura da época concluiu que a experiência bipartidária forçada imposta pelo regime militar ajudou a consolidar junto ao eleitorado a imagem do MDB como o partido do povo, que defendia o homem comum contra os poderosos, e que lutava pelas liberdades políticas e a volta das eleições diretas. Entre as análises produzidas na época, Reis (1988) assinala que esse partidarismo estava, em larga medida, desprovido de um ideário político coeso. Na sua expressão, "votar na oposição é, para o eleitor em questão, um pouco como 'torcer' por um clube popular de futebol". Essa "síndrome do Flamengo", de um lado, emprestava estabilidade e coesão ao quadro partidário de então; mas, de outro lado, mantinha as tradições simplistas da política populista, cujo discurso se constrói com a contraposição dos construtos amorfos de ricos contra os pobres.

Após a volta ao multipartidarismo, a análise do fenômeno da identificação partidária no Brasil teve continuidade. Se no período militar o desafio principal era entender a dinâmica do governismo e do oposicionismo no eleitorado, agora, a identificação partidária é usada como um termômetro da consolidação do novo sistema partidário. A questão central que essa literatura busca responder é: até que ponto os novos partidos seriam capazes de forjar laços de identidade e lealdade com os eleitores? As taxas globais de identidade partidária se tornam um indicador do enraizamento social dos partidos. Kinzo (2004) dá uma resposta pessimista a essa questão: "Em suma, a intensa fragmentação e a falta de nitidez do sistema partidário fazem com que os eleitores tenham dificuldade em fixar os partidos, distingui-los e, assim, conseguir criar identidades partidárias". No balanço comparativo das taxas de identificação partidária no eleitorado, o Brasil é um dos últimos colocados, tanto na América Latina (Pereira, 2012; Rennó et al., 2011, p. 141-148) como numa comparação global (Braga e Pimentel Jr., 2011; Plasser e Plasser, 2002, p. 304). 
Em relação às tendências temporais da evolução interna do partidarismo no Brasil, vários autores apontaram para o declínio do PMDB e a ascensão do PT nas últimas três décadas de pesquisas sobre identificação partidária (Carreirão e Kinzo, 2004; Venturi, 2010). Uma característica apontada por essas pesquisas é a assimetria no perfil dos simpatizantes de diferentes partidos. Tomando como referência a força eleitoral, os petistas são claramente sobrerrepresentados entre os eleitores que expressam identidade com algum partido, enquanto outros partidos praticamente não contam com uma base de eleitores identificados (Samuels, 2004). Mais recentemente Veiga analisou o perfil social dos simpatizantes comparando os maiores partidos (Veiga, 2007, 2011). Essa análise aponta variações importantes no perfil de simpatizantes de diferentes partidos, quando se consideram diferentes regiões, graus de escolaridade e diversos perfis ideológicos. Essa questão é especialmente debatida quando o tema é o perfil dos partidários do Partido dos Trabalhadores (PT). As contribuições de Singer (2010), Venturi (2010) e Samuels e Zucco (2014a) divergem sobre o momento e a direção da mudança do perfil dos simpatizantes desse partido após a vitória nas eleições presidenciais de 2002.

Há poucas respostas na literatura acadêmica nacional sobre as origens do partidarismo. O que é surpreendente, dadas as condições peculiares da origem do sistema partidário atual. Com poucas exceções, o sistema partidário pós-ditadura é composto por legendas recém-criadas. Somente quatro partidos poderiam reivindicar uma tradição de continuidade com o sistema partidário anterior. O PMDB se posicionou claramente como herdeiro do MDB, partido opositor do regime militar, inclusive mantendo o nome da nova sigla próxima à anterior. Os eleitores socializados durante os anos 1970 não teriam dificuldade em associar a nova sigla à herança do partido que se tornou símbolo da oposição ao regime e das conquistas democráticas. Mas o caso do PMDB é a exceção. O PSDB, cisão do PMDB ocorrida no final dos anos 1980, pouco explorou os seus vínculos com a corrente dos "autênticos" do antigo MDB. Os partidos herdeiros da Arena fizeram de tudo para justamente apagar os traços de continuidade. $O$ atual PP, anterior PPR, previamente PDS, herdeiro da Arena, o fez por meio da estratégia de mudar repetidamente o nome da sigla. O atual DEM, anterior PFL, cisão da antiga Arena, igualmente negou a sua tradição histórica. Em ambos os casos a continuidade da sigla, elemento essencial para a construção da identificação partidária no modelo psicossocial, foi intencionalmente apagada pelas lideranças políticas. Dois partidos, PTB e PDT, tentaram revitalizar raízes mais longínquas, com o antigo partido populista associado à herança varguista de antes do golpe. Aqui o conflito e a cisão dificultaram a continuidade, mas, sob a liderança política de Leonel Brizola, o PDT investiu no reestabelecimento do vínculo com a tradição trabalhista e com a figura de Getúlio Vargas. Finalmente a legalização do PCB, que teoricamente poderia reatar os vínculos com a traição comunista que data dos anos 1930, reavivada com o sucesso do partido nos anos 1950, primeiro na legalidade e depois na ilegalidade, teve a sua coesão abalada 
pelas cisões na esquerda durante o governo militar e os efeitos do colapso da União Soviética. Esse partido alterou sua sigla para PPS, rompendo com o passado. Vale lembrar ainda o caso do PT, partido que explicitamente enfatizava o rompimento com as tradições do trabalhismo do passado e apostava na novidade do novo modelo partidário proposto.

Portanto, no balanço, somente o PMDB e o PDT vincularam a sua imagem a tradições políticas herdadas do passado, explorando a possibilidade de que cidadãos socializados antes ou durante a ditadura transferissem a sua identificação política às novas siglas. Todos os outros partidos criados ou recriados desde a volta ao multipartidarismo, seja porque negaram a própria tradição, seja porque não tiverem antecedentes históricos, não poderiam contar com eleitores fidelizados pelo processo de socialização descrito pela literatura internacional, que toma como referência a experiência de países que possuem uma longa tradição partidária ininterrupta. Nessa circunstância histórica, a reduzida taxa de identidade partidária após a redemocratização pode ser consequência das peculiaridades do processo de emergência do novo sistema partidário descritas acima. Adicionalmente, o intenso e contínuo processo de fragmentação do sistema partidário brasileiro torna a fidelização do eleitor com um partido específico ainda mais difícil. Assim, as análises do processo de aquisição da identificação partidária no Brasil deveriam levar em conta essas peculiaridades do sistema partidário brasileiro que se formou após a democratização. Entretanto, a literatura brasileira registra pouca discussão sobre a aplicabilidade ou não do modelo que associa a formação da identidade partidária ao processo inicial de socialização política dos indivíduos ao caso brasileiro, ou eventuais modelos alternativos, que eventualmente descreveriam melhor o caso nacional.

Por outro lado, o questionamento da utilidade do conceito da identificação partidária para a pesquisa das relações entre eleitores e organizações partidárias tem longa tradição no Brasil. Na literatura, as pesquisas sobre a identidade partidária no Brasil são permeadas por uma dúvida mais fundamental sobre a aplicabilidade do conceito da identificação partidária no contexto do Brasil. Essa literatura discute a possibilidade de formação de identidades partidárias em um sistema partidário com um grande número de partidos, muitos deles de vida muito curta e com um eleitorado, em geral, com baixo nível de escolaridade e fraca capacidade de compreensão do processo político.

Por um lado Reis (1988) já havia lançado dúvida sobre a perenidade da identificação de parte do eleitorado com um ou outro partido político, dada a baixa sofisticação política que caracteriza o imaginário político expresso por uma grande parcela do eleitorado. Kinzo (2005) também faz um balanço negativo, quando avalia o impacto da identificação com diferentes partidos na estruturação do imaginário político dos eleitores. Vários outros trabalhos também testam, e questionam, a coerência das várias facetas da identificação partidária no eleitorado brasileiro, ora comparando várias 
medições da identificação (Paiva, Braga e Pimentel Jr., 2007; Pimentel Jr., 2007), ora comparando a identificação partidária com outros indicadores, tais como a filiação partidária (Speck, Braga e Costa, 2015). Um estudo de painel com três ondas de entrevistas concluiu pelo baixo impacto da identidade partidária sobre o comportamento eleitoral (Baker, Ames e Rennó, 2006). A análise dos mesmos dados, especificamente considerando perenidade da identificação partidária, revelou que uma parte considerável dos entrevistados mudou sua identificação partidária num período de poucos meses (Baker et al., 2015; Pereira, 2014). Em última instância, portanto, esses estudos questionam o alcance, a coerência e o impacto da identificação partidária no comportamento do eleitorado brasileiro. Poucos eleitores simpatizariam com partidos, a simpatia com um partido não implicaria necessariamente a rejeição de outro e, principalmente, a identidade partidária parece ter pouco poder preditivo sobre escolha eleitoral. Entretanto, contra essa interpretação dominante, o trabalho recente de Samuels e Zucco (2014b) encontrou resultados relevantes ao tentar dirimir as dúvidas sobre o significado da identificação partidária no Brasil por meio de um experimento. Esse estudo confirmou a importância da identificação partidária para a formação das opiniões políticas dos simpatizantes do PT e do PSDB, os dois partidos que funcionaram como âncoras da clivagem eleitoral brasileira desde, pelo menos, a eleição de 1994.

Diante de tantos questionamentos a respeito da utilidade da identificação partidária como instrumento heurístico relevante para as ciências sociais no Brasil, não surpreende que o número de trabalhos dedicados a analisar o impacto do partidarismo sobre o voto dos eleitores brasileiros seja reduzido. Entre estes estão Carreirão e Kinzo (2004) que analisam o impacto do partidarismo sobre o voto presidencial. Os autores concluem que, nas cinco eleições presidenciais entre 1989 e 2002, entre, aproximadamente, quatro eleitores que se identificaram com um partido, somente a metade votou no candidato de seu partido. Nicolau (2007) também analisou o impacto da identidade partidária sobre as eleições presidenciais usando regressão logística. Para as eleições de 2002 ele identifica um impacto significativo do partidarismo tanto entre eleitores que se identificavam com o PT como entre aqueles que expressavam preferência pelo PSDB. Em um estudo abrangendo as três eleições presidenciais de 2002 a 2010, Braga e Pimentel Jr. (2011) analisam o impacto do partidarismo, porém limitando a análise logística ao segundo turno, em que os candidatos do PT e do PSDB se enfrentaram isoladamente. Novamente a identificação partidária se revelou um forte fator de previsão. Mais do que isso, os dados desse estudo mostram que a IP teve um peso crescente na previsão do voto ao longo desse período. As análises do impacto da identificação partidária sobre o voto para outros cargos são menos frequentes. Pimentel Jr. (2007) analisou o impacto da identificação partidária sobre as eleições para governador em São Paulo, em 2002, e para presidente, no mesmo ano, recorrendo a simples correlações. O autor identifica coeficientes positivos significativos para todos os partidos que lançaram candidatos para os respectivos cargos, com os valores mais 
expressivos para o PT. Paiva e Tarouco (2011) se propõem a medir o impacto do partidarismo sobre a eleição para deputado federal em $2010^{2}$. Speck, Braga e Costa (2015) avaliaram o impacto da identificação partidária sobre o voto em 2014 usando regressão logística. Os autores avaliaram a votação para todos os cargos disputados na eleição, concluindo que os eleitores que expressam identificação partidária têm maior chance de votar no mesmo partido para os vários cargos disputados na eleição ${ }^{3}$.

Os resultados apresentados nessa revisão apontam para um paradoxo: de um lado, boa parte da literatura que analisa a identificação partidária no Brasil converge para o diagnóstico que aponta a sua baixa relevância para compreender a decisão de voto dos eleitores. Não apenas poucos eleitores expressam simpatia por algum partido específico, como, mesmo entre os que o fazem, a identidade partidária parece ter pouca relevância para a definição do voto. Entretanto, a literatura mais recente encontrou resultados interessantes, quando se toma isoladamente os eleitores que se identificam com o PT e o PSDB, os dois partidos que, como dissemos anteriormente, organizaram a competição eleitoral no Brasil desde, pelo menos, 1994. Essa literatura reúne indícios de que, pelo menos para esses eleitores, a identificação partidária não apenas tem consequências para a decisão do voto, mas também parece ser um elemento relevante para a compreensão que esses eleitores têm sobre temas e questões da política brasileira. 0 presente artigo tem por objetivo contribuir para esse debate.

\section{Dados usados e operacionalização das variáveis}

A partir dos dados coletados pela pesquisa do Eseb para as eleições de 2014, este artigo busca avaliar o impacto da identificação partidária no comportamento e nas atitudes políticas dos eleitores a partir de duas perspectivas: em primeiro lugar, em que medida conhecer a identificação partidária do eleitor aumenta a previsibilidade do voto e, em segundo lugar, qual a relação entre a identidade partidária e atitudes e opiniões expressas pelos eleitores. Os dois temas serão analisados nessa sequência. É importante ressaltar, porém, que a hipótese que organiza essa análise não supõe que a identificação partidária impacta uniformemente o voto e as opiniões dos eleitores. Ao contrário, esse estudo busca demonstrar que a forma como a identidade partidária influencia o voto difere tanto em relação ao campo político em que o eleitor se situa, como também em

\footnotetext{
${ }^{2}$ Apesar do teste de associação (qui-quadrado) entre identificação partidária e voto para deputado federal indicar um resultado positivo, as autoras concluem que, "Mesmo para aqueles que declaram 'gostar' de algum partido, a escolha do candidato a deputado federal não acompanha a declaração de preferência partidária. Os partidos brasileiros não estruturam o voto".

${ }^{3}$ Os cargos analisados são presidente (10 turno), governador (10 turno), senador, deputado federal e deputado estadual. O critério para a avaliação é o cidadão ter votado para 3 ou mais desses cargos do mesmo partido. A probabilidade de o voto coerente nesses termos ocorrer entre os cidadãos que gostam de um partido é o dobro em comparação com os outros cidadãos. A análise não avalia se o partido votado é o mesmo daquele com o qual o eleitor se identificou, nem leva em conta a estrutura de oportunidade da eleição (se havia candidato no estado). O presente artigo avança nos dois sentidos.
} 
relação ao seu status social. Compreender os efeitos moderadores complexos desses dois fatores é uma contribuição importante para fazer avançar o debate sobre o papel da identificação partidária no jogo eleitoral brasileiro.

No Eseb 2014, um em cada três entrevistados manifestou-se positivamente quando indagado se gostava de algum partido político. Qual é o significado e quais as consequências da identificação partidária no Brasil em relação à escolha do voto nessas eleições? Para responder a essa questão analisamos a extensão do partidarismo no Brasil e as consequências para a escolha eleitoral no pleito de 2014. Diferentemente de outros estudos anteriores, analisaremos o impacto do partidarismo sobre todas as eleições para os cinco cargos diferentes.

Há duas perguntas no Eseb 2014 que são candidatas para operacionalizar o conceito da identificação partidária. Pergunta 1: "Existe algum partido político que representa a maneira como o(a) sr(a). pensa?". Pergunta 2: "Existe algum partido político que o(a) sr(a). goste mais que os outros?". Ambas têm as opções sim e não como alternativas, além da opção de não responder ${ }^{4}$. A nossa variável independente da identificação partidária é construída como variável binária a partir da resposta "não" (0) e "sim" (1) à segunda pergunta. Os que não responderam são classificados como sem resposta e não foram considerados em nossa análise. O principal motivo para essa opção decorre do entendimento restrito da primeira questão, que pressupõe que a identidade partidária está baseada sempre numa relação de representação clara, o que, como vimos na revisão, é um pressuposto por demais exigente até mesmo em países onde a história partidária é mais longa.

Entretanto, para além da identificação partidária, outros fatores possivelmente influenciam a decisão de voto. Esses outros fatores compreendem as características demográficas herdadas (idade, sexo, cor) ou adquiridas (escolaridade, religião, estado civil), o contexto local (região, capital), o status socioeconômico (renda, ascensão, Bolsa Família), as disposições cognitivas individuais (informação sobre política, confiança na democracia) ou o contato com a política durante a campanha (contatado por políticos, amigos).

Todas essas variáveis foram codificadas como binárias. Quando possível, as categorias foram criadas dividindo a amostra em dois grupos aproximadamente iguais. As regiões do Brasil são operacionalizadas como variáveis dummies, tendo a região

\footnotetext{
${ }^{4}$ Deve-se notar que nenhuma das perguntas traduz exatamente o sentido da pergunta correspondente do Anes (American National Election Survey) aplicada nos surveys nos Estados Unidos desde 1952 a cada dois anos. "Generally speaking, do you usually think of yourself as a Republican, a Democrat, an Independent, or what?" (<http://www.electionstudies.org/nesguide/toptable/tab2a_1.htm>).

As diferenças na formulação da pergunta tornam a comparação dos resultados entre países questionável. A diferença de conteúdo entre as perguntas no Brasil e nos Estados Unidos é significativa e vai desde a noção mais forte de identidade e perenidade até a enumeração das alternativas. A pergunta no Brasil diz respeito à posição do partido, não à da identidade do entrevistado. Também não há um elemento na frase separando o sentimento temporário de um compromisso mais duradouro. As influências dessas formulações nas questões que operacionalizam o conceito da identificação partidária sobre os resultados das pesquisas são exemplificadas em Rennó (2011) para o assunto da confiança interpessoal.
} 
Sudeste como categoria de referência. As capitais são também identificadas com outra variável binária, tendo os entrevistados que residem em outras regiões como categoria de referência. Da mesma forma, a variável 'Mulheres' (1) tem como referência Homens (0); os 'Brancos' (1) se referem aos Não Brancos (0) e 'Idade' (1) identifica os entrevistados acima de 40 anos, com o grupo abaixo dessa idade como referência. A variável 'Escolaridade' (1) inclui os cidadãos com segundo grau completo ou mais em comparação com os demais; 'Estado Civil' (1) compara os casados com os demais; e 'Religião' (1) inclui os evangélicos em comparação com todos os outros.

As variáveis socioeconômicas incluem 'Renda', que compara os grupos que ganham mais de dois salários mínimos (1) com os demais (0); os que subjetivamente ascenderam (1) com os demais $(0)^{5}$ e os que recebem 'Bolsa Família' (0) com os demais (1). Invertemos a classificação desta última categoria para facilitar a leitura dessas diferentes classificações sociais em que (0) corresponde ao grupo em condições menos favoráveis e (1) aos mais privilegiados.

Finalmente as variáveis sobre as atividades políticas incluem 'Informação Política', uma variável construída a partir das respostas a quatro perguntas: "Pelo que $o$ (a) $\operatorname{sr}(a)$. sabe ou ouviu falar, qual dessas pessoas foi o ministro da Fazenda durante o governo Dilma"?; "Pelo que o(a) sr(a). sabe ou ouviu falar, qual dessas foi a taxa de desemprego do Brasil em agosto de 2014?", "E pensando no que o(a) sr(a). sabe ou ouviu falar, qual é hoje o segundo maior partido na Câmara dos Deputados?", e, finalmente, "Qual dessas pessoas é o atual secretário-geral da ONU - Organização das Nações Unidas?". Para cada uma das quatro perguntas o entrevistado era apresentado a 4 respostas, sendo uma correta. Em nossa análise, os entrevistados que identificaram pelo menos uma das perguntas corretamente foram codificados como (1), em comparação com os demais (0).

A variável 'Contato Político' se baseia na seguinte questão: "Durante a campanha eleitoral deste ano, o(a) sr(a). foi contatado(a) por algum partido político ou candidato pessoalmente ou de alguma outra forma?". Ela assume valor (1) para as respostas afirmativas e (0) para as negativas.

'Engajamento Político' é uma variável binária criada a partir das respostas às seguintes sete questões: "Agora vou citar algumas atividades e gostaria de saber se o(a) $\operatorname{sr}(a)$. já fez essa atividade em algum momento da sua vida: assinar um abaixo-assinado (inclusive na internet); participar de manifestações ou protestos de rua; participar de greve; participar de bloqueio de estradas; participar de ocupação de prédios públicos; participar de ocupação de terras; utilizar a internet ou redes sociais para manifestações e

\footnotetext{
${ }^{5}$ Essa variável resulta de várias questões nas quais o entrevistado avalia a sua situação social hoje (2014) com o momento de oito anos atrás. A comparação resulta em três possíveis situações nas quais o entrevistado se encontra: estagnação (avalia que está na mesma classe), ascensão (subiu) ou declínio (caiu). Como categoria de referência usamos a fusão entre as categorias 'declínio' e 'estagnação'.
} 
debates políticos". A variável assume valor (1) quando pelo menos uma das questões foi respondida afirmativamente e valor (0) para os demais.

É importante ressaltar que o nosso principal interesse está focado no efeito direto do partidarismo sobre a decisão do voto. O interesse nas variáveis que captam o perfil demográfico, social e econômico dos entrevistados é meramente instrumental. Queremos evitar a atribuição errônea de um efeito sobre a decisão do voto pela influência não controlada de uma das variáveis que captam a posição social do entrevistado.

\section{Identificação partidária e o voto consistente em diferentes eleições}

Agora avançamos para responder à questão a respeito do impacto da identificação partidária sobre o voto. Como mostramos na resenha da literatura, na maior parte dos estudos a resposta a essa questão toma por base a decisão do voto para a eleição presidencial. A inclusão de outras eleições demanda uma série de ajustes no desenho da análise. Isso porque em outros níveis não apenas o leque de opções é diferente, como o padrão das alianças pode variar.

Assim, a questão que colocamos precisa ser reformulada: até que ponto a identificação partidária ajuda a explicar o voto dos cidadãos em eleições para diferentes cargos? Nossa expectativa é de que os cidadãos que se identificam com determinado partido também tenham votado nos candidatos desse partido, ou na sua sigla, nos diferentes níveis de eleição em 2014. Até que ponto isso ocorreu? Para responder à questão precisamos filtrar os casos relevantes. Primeiro, a questão da congruência entre identificação e voto só faz sentido para o grupo que se identifica com algum partido (aproximadamente um terço dos entrevistados). Cidadãos sem preferência partidária não podem trair o seu partido na hora de votar.

Segundo, somente uma parte dos entrevistados se lembra da sua escolha eleitoral para os diferentes cargos. Sem poder confrontar a identificação partidária com a escolha do voto também não é possível avaliar a congruência do voto. A Tabela 1 mostra que a memória do voto é alta para os cargos de maior visibilidade (presidente, governador e senador), mas bastante baixa para os cargos de deputado federal e estadual. No caso das eleições para estes últimos, somente um quarto dos entrevistados identifica o partido em que votou. Assim, para esse nível de eleição a comparação entre identificação e escolha eleitoral automaticamente se reduz ao grupo que recorda o voto. 


\section{Tabela 1}

Memória do voto para os diferentes cargos nas eleições 2014 (\%)

\begin{tabular}{|l|c|c|c|c|c|}
\hline & $\begin{array}{c}\text { Presidente } \\
(\mathbf{1} \text { turno) }\end{array}$ & $\begin{array}{c}\text { Governador } \\
(\mathbf{1} \text { turno })\end{array}$ & Senador & $\begin{array}{c}\text { Deputado } \\
\text { federal }\end{array}$ & $\begin{array}{c}\text { Deputado } \\
\text { estadual }\end{array}$ \\
\hline Não compareceu & 9,1 & 9,1 & 9,1 & 9,1 & 9,1 \\
\hline Informa voto válido & 84,4 & 76,8 & 66,3 & 29,2 & 25,4 \\
\hline $\begin{array}{l}\text { Não informa voto } \\
\text { válido }\end{array}$ & 6,5 & 14,1 & 24,6 & 61,7 & 65,5 \\
\hline Total & 100,0 & 100,0 & 100,0 & 100,0 & 100,0 \\
\hline
\end{tabular}

Fonte: Eseb 2014, tabulação própria.

A terceira limitação diz respeito à estrutura de oportunidades da escolha eleitoral. Nem todos os partidos apresentaram candidatos a todos os cargos nos diferentes estados e, consequentemente, muitos dos eleitores não puderam votar em candidatos dos partidos de sua preferência nessas eleições. Identificar o eleitor que se identifica com um partido e com uma situação de escolha efetiva demanda filtrar todos os casos nos quais o partido não apresentou um candidato para determinado cargo. Na eleição para presidente somente 11 partidos apresentaram candidatos. Nas eleições para os outros cargos, a estrutura de oportunidade para a escolha do partido preferido é mais complexa. $\mathrm{Na}$ Tabela 2 reproduzimos de forma reduzida quais partidos apresentaram candidatos para governador, senador, deputado federal e estadual nos respectivos estados. Destacamos somente as candidaturas dos partidos PT, PMDB e PSDB para os quatro cargos. Essa tabela mostra que, principalmente para os cargos majoritários de governador e senador, é frequente a situação na qual os partidos não têm candidato disputando (candidatos a vice ou suplentes não foram considerados). Incluir os eleitores desses estados com identidade partidária na análise produziria um viés negativo na avaliação da fidelidade desses eleitores. 
Tabela 2

Apresentação de candidaturas para os diferentes cargos nas eleições de 2014

\begin{tabular}{|c|c|c|c|c|c|c|c|c|c|c|c|c|c|c|c|c|}
\hline \multirow[b]{2}{*}{ UF } & \multicolumn{4}{|c|}{ Governador } & \multicolumn{4}{|c|}{ Senador } & \multicolumn{4}{|c|}{ Deputado federal } & \multicolumn{4}{|c|}{ Deputado estadual } \\
\hline & PT & PMDB & PSDB & OUTR & PT & PMDB & PSDB & OUTR & PT & PMDB & PSDB & OUTR & PT & PMDB & PSDB & OUTR \\
\hline$A C$ & & 1 & & 3 & & 1 & & 3 & & 1 & 1 & 25 & & 1 & 1 & 25 \\
\hline $\mathrm{AL}$ & & & 1 & 8 & & & 1 & 8 & 1 & 1 & 1 & 24 & 1 & 1 & 1 & 27 \\
\hline$A M$ & & 1 & & 6 & & 1 & & 5 & 1 & 1 & 1 & 27 & 1 & 1 & 1 & 27 \\
\hline AP & & & & 7 & & & & 10 & 1 & 1 & 1 & 25 & 1 & 1 & 1 & 24 \\
\hline $\mathrm{BA}$ & 1 & & & 5 & 1 & & & 4 & 1 & 1 & 1 & 26 & 1 & 1 & 1 & 26 \\
\hline $\mathrm{CE}$ & & 1 & & 3 & & 1 & & 3 & 1 & 1 & 1 & 27 & 1 & 1 & 1 & 27 \\
\hline DF & 1 & & 1 & 4 & 1 & & 1 & 6 & 1 & 1 & 1 & 28 & 1 & 1 & 1 & 28 \\
\hline ES & & 1 & & 5 & & 1 & & 5 & 1 & 1 & 1 & 28 & 1 & 1 & 1 & 28 \\
\hline GO & 1 & 1 & 1 & 6 & 1 & 1 & 1 & 6 & 1 & 1 & 1 & 27 & 1 & & 1 & 21 \\
\hline MA & & 1 & & 5 & & 1 & & 5 & 1 & 1 & 1 & 27 & 1 & 1 & 1 & 27 \\
\hline MG & 1 & & 1 & 6 & 1 & & 1 & 6 & 1 & 1 & 1 & 28 & 1 & 1 & 1 & 28 \\
\hline MS & & 1 & 1 & 4 & & 1 & 1 & 5 & 1 & 1 & 1 & 26 & 1 & 1 & 1 & 26 \\
\hline MT & 1 & & & 4 & 1 & & & 4 & & & 1 & 24 & & 1 & 1 & 25 \\
\hline PA & & 1 & 1 & 4 & & 1 & 1 & 9 & 1 & 1 & 1 & 27 & 1 & 1 & 1 & 26 \\
\hline PB & & 1 & 1 & 4 & & 1 & 1 & 6 & 1 & 1 & 1 & 27 & & 1 & 1 & 27 \\
\hline $\mathrm{PE}$ & & 1 & & 5 & & 1 & & 4 & 1 & 1 & 1 & 27 & 1 & 1 & 1 & 27 \\
\hline PI & 1 & 1 & & 5 & 1 & 1 & & 4 & 1 & 1 & 1 & 27 & 1 & 1 & 1 & 27 \\
\hline PR & 1 & 1 & 1 & 5 & 1 & 1 & 1 & 5 & 1 & 1 & 1 & 27 & 1 & 1 & 1 & 27 \\
\hline RJ & 1 & 1 & & 5 & 1 & 1 & & 6 & 1 & 1 & 1 & 27 & 1 & 1 & 1 & 28 \\
\hline RN & & 1 & & 4 & & 1 & & 4 & 1 & 1 & 1 & 25 & 1 & 1 & 1 & 25 \\
\hline RO & 1 & 1 & 1 & 3 & & 1 & 1 & 4 & 1 & 1 & 1 & 25 & 1 & 1 & 1 & 25 \\
\hline $\mathrm{RR}$ & 1 & & & 3 & 1 & & 1 & 4 & 1 & 1 & 1 & 26 & 1 & 1 & 1 & 26 \\
\hline RS & 1 & 1 & & 6 & 1 & 1 & & 5 & 1 & 1 & 1 & 26 & 1 & 1 & 1 & 26 \\
\hline SC & 1 & & & 7 & 1 & & & 6 & 1 & 1 & 1 & 26 & 1 & 1 & 1 & 27 \\
\hline SE & 1 & & & 4 & 1 & & & 4 & 1 & 1 & 1 & 25 & 1 & 1 & 1 & 27 \\
\hline SP & 1 & 1 & 1 & 6 & 1 & 1 & 1 & 7 & 1 & 1 & 1 & 27 & 1 & 1 & 1 & 28 \\
\hline TO & & 1 & & 5 & & 1 & & 5 & & 1 & 1 & 27 & & 1 & 1 & 27 \\
\hline
\end{tabular}

Fonte: TSE, tabulação própria.

Assim, as análises nesta seção levam em conta essas três limitações. A base de dados é reduzida aos entrevistados que têm preferência partidária, que recordam da sua escolha eleitoral e cujos partidos apresentaram candidatos.

Podemos agora voltar à questão do impacto da identificação partidária sobre a escolha eleitoral. Para os simpatizantes que se identificam com determinado partido, e que tiveram a chance de votar nos candidatos do seu partido, há duas possibilidades: ou 
votaram nesse candidato ou o preteriram, dando seu voto para um candidato de outro partido. Classificamos o primeiro caso como voto congruente. A Tabela 3 identifica quantos dos simpatizantes votam no partido de sua preferência para os cinco cargos disputados. A taxa de adesão é grande para as eleições presidenciais (83\%), mas apresenta um índice bem menor para as eleições dos outros cargos. Somente metade dos simpatizantes orienta seu voto a governador em função da preferência partidária. Nas eleições para o Senado essa taxa cai para um terço e para deputado federal e estadual, para um quarto. Isso já mostra que a identificação partidária tem significado parcial sobre as escolhas eleitorais no Brasil. Enquanto ela influencia fortemente as eleições presidenciais, o seu impacto sobre a escolha eleitoral para outros cargos é reduzido.

Tabela 3

Taxa de congruência entre identificação partidária e voto nas eleições 2014 (\%)

\begin{tabular}{|c|c|c|c|c|c|}
\hline $\begin{array}{c}\text { Simpatizantes } \\
\text { votam no } \\
\text { candidato do } \\
\text { partido a ... }\end{array}$ & $\begin{array}{c}\text {... presidente, } \\
\text { quando este } \\
\text { apresenta } \\
\text { candidato? }\end{array}$ & $\begin{array}{c}\text {... governador, } \\
\text { quando este } \\
\text { apresenta } \\
\text { candidato? }\end{array}$ & $\begin{array}{c}\text {... senador, } \\
\text { quando este } \\
\text { apresenta } \\
\text { candidato? }\end{array}$ & $\begin{array}{c}\text {... deputado } \\
\text { federal, } \\
\text { quando este } \\
\text { apresenta } \\
\text { candidato? }\end{array}$ & $\begin{array}{c}\text {... deputado } \\
\text { estadual, } \\
\text { quando este } \\
\text { apresenta } \\
\text { candidato? }\end{array}$ \\
\hline não & 17 & 43 & 66 & 75 & 76 \\
\hline $\operatorname{sim}$ & 83 & 57 & 34 & 25 & 24 \\
\hline
\end{tabular}

Fonte: Eseb 2014, tabulação própria.

No próximo passo aprofundamos as análises sobre a congruência entre identificação partidária e escolha eleitoral em duas dimensões. Primeiro queremos saber se a congruência entre identidade partidária e voto é influenciada por outros fatores. Ou seja, em que medida diferenças entre as regiões, entre capital e interior, a situação socioeconômica dos entrevistados ou as suas características demográficas importam? Para responder a essa questão, usamos as variáveis de controle definidas acima para nosso exercício de regressão logística.

A segunda questão diz respeito a diferenças de comportamento entre os simpatizantes de diferentes partidos políticos. Como vimos acima, parte da literatura indica que a identidade partidária tem significados distintos para eleitores simpatizantes de diferentes partidos. Assim, nossa análise foca os eleitores que manifestaram identidade com os três maiores partidos na eleição de 2014, PT, PSDB e PMDB. Nossa análise indica que esses eleitores apresentam taxas de congruência diferentes em relação aos simpatizantes de todos os outros partidos. Para obter esse resultado criamos variáveis binárias que tomam como base a identidade com cada um desses três partidos, mantendo os partidos restantes como categoria de referência. 
A Tabela 4 compila os resultados das cinco regressões logísticas separadas para explicar a congruência do voto para cada um dos votos para presidente (10 turno), governador (10 turno), senador, deputado federal e deputado estadual. As primeiras três variáveis explicativas dizem respeito aos simpatizantes do PT, do PMDB e do PSDB. As variáveis restantes testam o impacto de fatores como região, status socioeconômico e perfil demográfico dos entrevistados.

Os resultados dessas regressões mostram que, para as eleições presidenciais, os simpatizantes do PT tiveram 38,3 vezes mais chances de votar na candidata do seu partido em comparação com os simpatizantes dos outros partidos confrontados com a mesma escolha. Os simpatizantes do PSDB tiveram apenas 10,7 vezes mais chances de votar no seu candidato, quando comparados com as chances de eleitores de outros partidos de votar em seus candidatos. Como os simpatizantes do PMDB não puderam votar no seu candidato, não foram incluídos na avaliação ${ }^{6}$.

No caso do PSDB, a influência do partidarismo sobre a decisão de voto aumenta para os outros níveis de eleição. Para esses eleitores a sequência vai das eleições a presidente (10,7 vezes), a governador (19,4 vezes) e a senador (31,1 vezes). Já o comportamento dos partidários do PT é diametralmente oposto. Enquanto a probabilidade de votar no próprio candidato a presidente era 38 vezes maior entre os petistas, para governador, essa taxa é de apenas 2,9 vezes maior e é estatisticamente não significativa para a escolha do candidato ao Senado. Para a decisão do voto ao Senado, não há diferenças estatisticamente significativas entre petistas e partidários de outros partidos no que tange à sua decisão ser definida a partir da sua identidade partidária.

Para as eleições para deputado federal o impacto positivo do partidarismo sobre candidatos do PT volta a ser significativo. Entretanto, um dado que requer investigação adicional é o impacto negativo do petismo sobre a eleição dos deputados estaduais. Para os simpatizantes do PSDB a força do partidarismo nas eleições legislativas não é diferente da observada para o restante das bases dos outros partidos. No caso dos simpatizantes do PMDB não houve nenhuma diferença significativa em relação à eleição de políticos do mesmo partido para nenhum dos cargos.

O resultado dessas análises mostra que a identidade com diferentes partidos tem impacto variado na escolha eleitoral. Para os petistas, o cargo central, que demanda mobilização e lealdade, é a presidência. Para os peessedebistas, as eleições subnacionais para governador e senador são mais importantes, mas a eleição para a presidência também mobiliza. Finalmente, a capacidade do PMDB de traduzir a empatia dos seus partidários em votos é bastante reduzida.

\footnotetext{
${ }^{6}$ Uma possibilidade seria incluir os candidatos a vice (na eleição para presidente e governador) e os suplentes (na eleição para senador) nas opções válidas para os simpatizantes dos partidos. Mas nem sempre os vice têm visibilidade na eleição e os suplentes para o Senado são desconhecidos para o eleitor comum. Optamos por incluir somente os candidatos principais.
} 
Como podemos entender esses resultados? Sugerimos que a análise de Melo e Câmara (2012) sobre as estratégias diferentes dos partidos brasileiros para disputar eleições no âmbito nacional e estadual oferece uma pista. Para o caso do PT e do PSDB, os autores identificam uma estratégia histórica de priorização das eleições presidenciais na mobilização política do eleitorado. Especialmente para o PT, a candidatura de seu líder mais importante, Luiz Inácio Lula da Silva, ao cargo de presidente da República em todas as eleições anteriores a 2010 e a vitória nas eleições de 2002 e 2006 tiveram um valor simbólico importante, que mobilizou seu eleitorado para esse cargo. Por outro lado, as disputas subnacionais são mais importantes para outros partidos, que não têm capacidade para lançar candidatos competitivos no âmbito nacional. Os resultados de nossa análise são congruentes com a hipótese de Melo e Câmara. Assim, podemos concluir que as estratégias de mobilização eleitoral adotadas pelas lideranças de diferentes partidos são responsáveis pela variedade de padrões de decisão eleitoral dos eleitores filiados a esses partidos. Essa hipótese preliminar a respeito do mecanismo causal por trás dos resultados discrepantes que encontramos para os eleitores dos três maiores partidos brasileiros (PT, PSDB e PMDB) requer pesquisas adicionais. No presente artigo nos limitamos a apontar esses padrões de comportamento, que até agora não haviam sido identificados na literatura sobre o caso brasileiro.

Quando consideramos o impacto das variáveis demográficas, regionais e de status social, vemos que, em relação à escolha do candidato à presidência, o impacto do partidarismo sobre o comportamento eleitoral independe da região. Entretanto, nas eleições subnacionais para governador o partidarismo é mais fraco no Sul e mais forte no Nordeste, quando comparado com a categoria de referência, Sudeste. Nas eleições para senador é na região Sudeste onde a identidade partidária tem maior impacto para a definição do voto para esse cargo. É provável que esses resultados sejam influenciados pela dominância do PSDB no estado de São Paulo. Finalmente cabe ressaltar o fator religião, que tem influência negativa sobre o partidarismo nas eleições para presidente, mas perde importância nas eleições para os outros cargos. Isso pode, em parte, ser explicado pela presença de duas candidaturas ligadas às igrejas evangélicas (Marina da Silva e Pastor Everaldo) para esse nível de eleição. 
Tabela 4

Regressão logística para explicar o voto congruente dos simpatizantes para vários cargos

\begin{tabular}{|c|c|c|c|c|c|c|c|c|c|}
\hline & voto pres $1 \mathrm{t}$ & & $\begin{array}{r}\text { voto gove } \\
1 \mathrm{t} \\
\end{array}$ & & voto sena $1 \mathrm{t}$ & & $\begin{array}{r}\text { voto depfed } \\
1 \mathrm{t} \\
\end{array}$ & $\begin{array}{r}\text { voto depest } \\
1 \mathrm{t} \\
\end{array}$ & \\
\hline & $\begin{array}{r}\text { razão de } \\
\text { chances }\end{array}$ & & $\begin{array}{l}\text { razão de } \\
\text { chances }\end{array}$ & & $\begin{array}{r}\text { razão de } \\
\text { chances }\end{array}$ & & $\begin{array}{l}\text { razão de } \\
\text { chances }\end{array}$ & $\begin{array}{l}\text { razão de } \\
\text { chances }\end{array}$ & \\
\hline & Erro-padrão & & Erro-padrão & & Erro-padrão & & Erro-padrão & Erro-padrão & \\
\hline \multirow[t]{2}{*}{ partidário PT } & 38,26 & $* * *$ & 2,92 & $*$ & 2,41 & & 2,33 & 0,34 & $*$ \\
\hline & 18,81 & & 1,42 & & 1,70 & & 1,14 & 0,16 & \\
\hline \multirow[t]{2}{*}{ partidário PMDB } & 1,00 & & 1,86 & & 4,77 & & 3,04 & 0,91 & \\
\hline & (.) & & 1,15 & & 4,13 & & 1,78 & 0,51 & \\
\hline \multirow[t]{2}{*}{ partidário PSDB } & 10,72 & $* * *$ & 19,44 & $* * *$ & 31,13 & $* * *$ & 1,27 & 0,45 & \\
\hline & 4,87 & & 11,12 & & 23,65 & & 0,64 & 0,23 & \\
\hline \multirow[t]{2}{*}{ morador Norte } & 0,51 & & 0,55 & & 0,06 & $*$ & 0,51 & 1,39 & \\
\hline & 0,28 & & 0,46 & & 0,08 & & 0,28 & 0,75 & \\
\hline \multirow{2}{*}{ morador Nordeste } & 0,52 & & 5,53 & $* * *$ & 0,24 & $* *$ & $0,45 *$ & 0,69 & \\
\hline & 0,18 & & 1,95 & & 0,11 & & 0,15 & 0,25 & \\
\hline \multirow[t]{2}{*}{ morador Sul } & 0,91 & & 0,27 & $* * *$ & 0,32 & $* *$ & 0,52 & 0,43 & \\
\hline & 0,45 & & 0,10 & & 0,13 & & 0,23 & 0,23 & \\
\hline \multirow[t]{2}{*}{ morador Centro-Oeste } & 2,38 & & 0,21 & $*$ & 0,09 & & 0,46 & 2,46 & \\
\hline & 2,74 & & 0,13 & & 0,11 & & 0,41 & 2,21 & \\
\hline \multirow{2}{*}{ vive na capital } & 1,11 & & 0,97 & & 1,52 & & 1,21 & 2,56 & $* *$ \\
\hline & 0,35 & & 0,29 & & 0,50 & & 0,39 & 0,90 & \\
\hline \multirow[t]{2}{*}{ é mulher } & 0,57 & $*$ & 1,01 & & 1,07 & & 1,00 & 0,58 & \\
\hline & 0,15 & & 0,25 & & 0,30 & & 0,28 & 0,19 & \\
\hline \multirow[t]{2}{*}{ é branco } & 1,33 & & 1,22 & & 1,34 & & 1,17 & 0,69 & \\
\hline & 0,43 & & 0,31 & & 0,38 & & 0,35 & 0,25 & \\
\hline \multirow[t]{2}{*}{ tem 40 anos ou mais } & 1,17 & & 1,15 & & 1,19 & & 0,95 & 1,75 & \\
\hline & 0,33 & & 0,31 & & 0,37 & & 0,29 & 0,59 & \\
\hline \multirow[t]{2}{*}{ tem $2^{\circ}$ grau ou mais } & 1,35 & & 0,75 & & 1,28 & & 0,82 & 0,68 & \\
\hline & 0,46 & & 0,20 & & 0,40 & & 0,30 & 0,25 & \\
\hline \multirow[t]{2}{*}{ é casado } & 0,82 & & 0,62 & & 0,85 & & 0,84 & 0,77 & \\
\hline & 0,24 & & 0,18 & & 0,28 & & 0,24 & 0,26 & \\
\hline \multirow[t]{2}{*}{ é evangélico } & 0,46 & $*$ & 0,82 & & 0,76 & & 1,06 & 1,52 & \\
\hline & 0,14 & & 0,25 & & 0,28 & & 0,36 & 0,56 & \\
\hline \multirow[t]{2}{*}{ ganha acima de 2 SM } & 0,91 & & 1,42 & & 1,48 & & 0,82 & 2,13 & $*$ \\
\hline & 0,28 & & 0,41 & & 0,45 & & 0,26 & 0,74 & \\
\hline
\end{tabular}


IDENTIFICAÇÃO PARTIDÁRIA E VOTO. AS DIFERENÇAS ENTRE PETISTAS E PEESSEDEBISTAS

\begin{tabular}{|c|c|c|c|c|c|}
\hline & voto pres $1 \mathrm{t}$ & $\begin{array}{r}\text { voto gove } \\
1 \mathrm{t} \\
\end{array}$ & voto sena $1 \mathrm{t}$ & $\begin{array}{r}\text { voto depfed } \\
1 \mathrm{t} \\
\end{array}$ & $\begin{array}{r}\text { voto depest } \\
1 \mathrm{t} \\
\end{array}$ \\
\hline & $\begin{array}{r}\text { razão de } \\
\text { chances }\end{array}$ & $\begin{array}{r}\text { razão de } \\
\text { chances }\end{array}$ & $\begin{array}{r}\text { razão de } \\
\text { chances }\end{array}$ & $\begin{array}{c}\text { razão de } \\
\text { chances }\end{array}$ & $\begin{array}{r}\text { razão de } \\
\text { chances }\end{array}$ \\
\hline & erro padrão & erro padrão & erro padrão & erro padrão & erro padrão \\
\hline \multirow[t]{2}{*}{ subiu de classe } & 0,77 & 0,73 & 0,71 & 1,01 & 1,68 \\
\hline & 0,22 & 0,18 & 0,21 & 0,28 & 0,54 \\
\hline \multirow[t]{2}{*}{ Bolsa Família } & 1,41 & 0,76 & 0,65 & 0,85 & 0,69 \\
\hline & 0,44 & 0,24 & 0,22 & 0,30 & 0,27 \\
\hline \multirow[t]{2}{*}{ mais informado } & 1,17 & 1,28 & 1,42 & 2,21 & 1,28 \\
\hline & 0,31 & 0,34 & 0,43 & 0,77 & 0,45 \\
\hline \multirow[t]{2}{*}{$\begin{array}{l}\text { contatado na } \\
\text { campanha }\end{array}$} & 0,62 & 0,77 & $0,56 *$ & 1,38 & 1,10 \\
\hline & 0,16 & 0,20 & 0,16 & 0,38 & 0,32 \\
\hline \multirow[t]{2}{*}{ mais ativista } & 1,01 & 1,50 & 1,39 & 0,88 & 0,62 \\
\hline & 0,28 & 0,40 & 0,44 & 0,27 & 0,20 \\
\hline \multirow[t]{2}{*}{ constante } & 0,57 & 0,41 & $0,13 *$ & 0,20 & 0,47 \\
\hline & 0,40 & 0,30 & 0,12 & 0,15 & 0,36 \\
\hline pseudo R-sqr & 0,22 & 0,197 & 0,309 & 0,061 & 0,122 \\
\hline
\end{tabular}

Fonte: Eseb 2014, tabulação própria.

$* \mathrm{p}<0.05, * * \mathrm{p}<0.01, * * * \mathrm{p}<0.001$.

\section{A mediação do impacto da identidade partidária sobre o voto}

Após estabelecer que o partidarismo tem pesos diferentes para a decisão eleitoral de petistas e peessedebistas, vamos agora examinar se o significado do partidarismo é o mesmo para os cidadãos pertencentes a diferentes grupos na sociedade. Nossa hipótese é de que a identificação partidária tem consequências diferentes para distintos setores. Enquanto para alguns a identificação partidária expressa uma afiliação pouco problematizada do ponto de vista político (algo que poderia se assemelhar a pertencer a uma torcida de futebol, no sentido sugerido por Reis), para outros a dinâmica do debate eleitoral tem um papel importante e outros fatores influenciam na tradução da identidade partidária em voto.

Essa ideia já estava presente na concepção de Lazarsfeld, um dos pais do conceito da identificação partidária. Segundo ele a identificação poderia ter origem tanto em um conjunto de conviç̧ões políticas, expressas também no partido, como também na rotinização pouco refletida de padrões de votação que depois ganha a etiqueta de afinidade partidária. A hipótese do impacto mediado da identificação também já tinha sido proposta por Balbachevsky (1992) que argumentou que eleitores pobres e menos instruídos provavelmente levariam mais em conta as orientações políticas dos seus 
partidos. Os eleitores mais instruídos e pertencentes a estratos sociais mais altos ponderam entre fidelidade e as informações colhidas durante a campanha. Para estes o efeito do partidarismo sobre o voto é moderado (ou pode ser reforçado) pelas informações trazidas pelos embates políticos na campanha eleitoral. É importante ressaltar a diferença entre esse efeito moderador do pertencimento a diferentes estratos sociais e a caracterização do perfil social ou geográfico dos setores identificados com diferentes partidos políticos, tal como apresentada por Samuels, Venturi ou Veiga, citados acima.

Com o intuito de testar essa hipótese incluímos na nossa análise variáveis que podem servir como proxies no sentido de identificar grupos para os quais o partidarismo teria efeito diferente sobre o comportamento eleitoral. Renda, instrução e Bolsa Família são variáveis que captam, de forma diferente, se o entrevistado está incluído entre os setores mais desfavorecidos da sociedade ou não. A operacionalização das três variáveis permite identificar os $29,7 \%$ dos cidadãos mais necessitados que recebem Bolsa Família, os $40,6 \%$ que têm escolaridade até o segundo grau incompleto ou os $35,6 \%$ da população que ganha até dois salários mínimos. São três formas diferentes de captar o grupo mais desfavorecido. O grupo oposto tem características mais heterogêneas, abrangendo todos os cidadãos que não recebem Bolsa Família, ganhando acima de dois salários mínimos até o topo da pirâmide salarial, e tendo instrução que vai do ensino médio completo até o pequeno grupo de cidadãos com formação universitária completa. Em termos de acesso aos bens materiais e simbólicos da sociedade, o primeiro grupo dos desfavorecidos é mais homogêneo do que o segundo grupo.

Essas três variáveis já estavam incluídas na regressão como variáveis aditivas de controle. Para avaliar se a condição de beneficiário do programa Bolsa Família tem efeito moderador sobre a relação entre partidarismo e voto, incluímos a variável Bolsa Família com um termo de interação com o partidarismo na regressão. Da mesma forma, partindo do pressuposto que escolaridade e renda são duas aproximações para captar a divisão social da sociedade brasileira, incluímos as duas variáveis, que também constam como variáveis aditivas no modelo anterior, agora como termos de interação com o partidarismo na regressão.

A análise a seguir se limita à eleição presidencial, em que, como vimos, o impacto da identificação partidária é mais forte. Ademais, o estudo contrasta os eleitores que manifestaram identidade com o PT ou o PSDB e os eleitores dos demais partidos, já que a análise anterior mostrou que esses dois partidos foram bem-sucedidos em traduzir o apoio na sociedade em votos. A regressão multivariada com o voto congruente (definida como a situação na qual o partidário vota no candidato do seu partido) para presidente como variável dependente inclui como variáveis de interesse o partidarismo (pró-PT e pró-PSDB) e as diferentes classificações binárias da sociedade (pelo acesso ao Bolsa Família, pela renda ou pela educação). Os modelos de regressão combinam separadamente as duas modalidades do partidarismo com as três variações de 
classificação da sociedade, resultando em seis regressões logísticas multivariadas. Em cada um desses modelos as duas variáveis de interesse entraram como termos constitutivos, mas também na forma de interação. Adicionalmente, as outras variáveis de controle foram mantidas.

Os resultados da Tabela 5 mostram que tanto o partidarismo pró-PT como o próPSDB influenciou significativamente a decisão de voto para presidente, tal como já tínhamos identificado anteriormente. No entanto, os termos de interação são significativos em cinco dos seis modelos, indicando que essa relação entre identificação partidária e voto se dá de forma diferente entre a parcela mais afluente da população e os mais pobres, entre os beneficiários do programa Bolsa Família e o resto da população, e entre os menos instruídos e os mais instruídos. Somente em relação à combinação entre petismo e educação o coeficiente do componente de interação não foi significativo. Esses resultados constituem fortes indícios de que a identidade partidária tem consequências diferentes não somente entre eleitores de diferentes partidos, mas também entre diferentes segmentos da sociedade.

Avaliamos as interações em duas etapas: primeiro, interpretando os coeficientes dos componentes principais e das interações, depois analisando os gráficos sobre os efeitos marginais dos dois fatores de interesse.

Os resultados apontam interações negativas entre 0 partidarismo e os indicadores que identificam o pertencimento aos segmentos mais privilegiados da sociedade. Para os petistas mais afluentes, mais instruídos e não beneficiários do programa Bolsa Família, a identificação com o PT não leva necessariamente ao voto no candidato do PT a presidente. Entre os eleitores petistas pertencentes aos setores menos privilegiados, a identificação partidária reforça a escolha congruente. Os dados mostram que ser petista e não necessitar do Bolsa Família reduz a chance de votar no candidato do partido pela metade. O impacto de ter alcançado escolaridade média ou superior ou renda superior a dois salários mínimos (SM) sobre o petismo é igualmente negativo. No caso da renda é ainda mais grave, reduzindo a probabilidade de votar no candidato do partido para um quinto. O efeito da interação no caso dos partidários do PSDB vai na direção oposta, mas ele é menos acentuado. Os peessedebistas de escolaridade média ou superior e de renda superior a dois SM têm mais chances de votar de forma coerente com a sua identificação partidária do que os partidários dos demais partidos. 
Tabela 5

Regressão logística com interação para explicar o voto congruente dos simpatizantes para presidente

\begin{tabular}{|c|c|c|c|c|c|c|c|c|c|c|c|c|}
\hline & $\begin{array}{r}\text { PT x } \\
\text { s/Bolsa } \\
\end{array}$ & & $\begin{array}{r}\text { PT x } \\
\text { escol. }\end{array}$ & & PT $x$ renda & & $\begin{array}{l}\text { PSDB X } \\
\text { s/Bolsa }\end{array}$ & & $\begin{array}{r}\text { PSDB X } \\
\text { escol. }\end{array}$ & & $\begin{array}{r}\text { PSDB } x \\
\text { renda }\end{array}$ & \\
\hline & $\begin{array}{r}\text { razão } \\
\text { de } \\
\text { chances } \\
\text { Erro- } \\
\text { padrão } \\
\end{array}$ & & $\begin{array}{r}\text { razão de } \\
\text { chances } \\
\text { Erro- } \\
\text { padrão } \\
\end{array}$ & & $\begin{array}{r}\text { razão de } \\
\text { chances } \\
\text { Erro- } \\
\text { padrão }\end{array}$ & & $\begin{array}{r}\text { razão de } \\
\text { chances } \\
\text { Erro- } \\
\text { padrão } \\
\end{array}$ & & $\begin{array}{r}\text { razão de } \\
\text { chances } \\
\text { Erro- } \\
\text { padrão } \\
\end{array}$ & & $\begin{array}{r}\text { razão } \\
\text { de } \\
\text { chances } \\
\text { Erro- } \\
\text { padrão } \\
\end{array}$ & \\
\hline \multirow[t]{2}{*}{ partidário PT } & 123,05 & $* * *$ & 72,52 & $* * *$ & 129,99 & $* * *$ & 34,70 & $* * *$ & 32,45 & $* * *$ & 30,90 & $* * *$ \\
\hline & 91,99 & & 53,90 & & 91,46 & & 16,97 & & 15,66 & & 14,82 & \\
\hline \multirow[t]{2}{*}{$\begin{array}{l}\text { partidário } \\
\text { PSDB }\end{array}$} & 11,77 & $* * *$ & 12,11 & $* * *$ & 13,81 & $* * *$ & 2,93 & & 4,26 & $*$ & 3,10 & \\
\hline & 5,79 & & 5,99 & & 6,93 & & 1,85 & & 2,85 & & 1,93 & \\
\hline \multirow[t]{2}{*}{$\begin{array}{l}\text { vive na } \\
\text { capital }\end{array}$} & 1,12 & & 1,04 & & 1,10 & & 1,08 & & 1,03 & & 1,05 & \\
\hline & 0,35 & & 0,31 & & 0,33 & & 0,33 & & 0,30 & & 0,32 & \\
\hline \multirow[t]{2}{*}{ é mulher } & 0,62 & & 0,61 & & 0,64 & & 0,65 & & 0,61 & & 0,63 & \\
\hline & 0,16 & & 0,16 & & 0,17 & & 0,17 & & 0,16 & & 0,17 & \\
\hline \multirow[t]{2}{*}{ é branco } & 1,50 & & 1,51 & & 1,44 & & 1,45 & & 1,53 & & 1,38 & \\
\hline & 0,45 & & 0,47 & & 0,44 & & 0,44 & & 0,47 & & 0,42 & \\
\hline \multirow[t]{2}{*}{$\begin{array}{l}\text { tem } 2^{\circ} \text { grau } \\
\text { ou mais }\end{array}$} & 1,30 & & 2,44 & & 1,29 & & 1,35 & & 0,96 & & 1,32 & \\
\hline & 0,45 & & 1,31 & & 0,43 & & 0,45 & & 0,38 & & 0,43 & \\
\hline \multirow[t]{2}{*}{ é casado } & 0,77 & & 0,81 & & 0,80 & & 0,77 & & 0,79 & & 0,79 & \\
\hline & 0,23 & & 0,23 & & 0,24 & & 0,23 & & 0,23 & & 0,23 & \\
\hline \multirow[t]{2}{*}{ é evangélico } & 0,47 & $*$ & 0,47 & $*$ & 0,44 & $* *$ & 0,45 & $* *$ & 0,46 & $*$ & 0,44 & $* *$ \\
\hline & 0,14 & & 0,14 & & 0,14 & & 0,14 & & 0,14 & & 0,13 & \\
\hline \multirow[t]{2}{*}{$\begin{array}{l}\text { ganha acima } \\
\text { de } 2 \text { SM }\end{array}$} & 1,02 & & 1,03 & & 2,89 & $*$ & 1,03 & & 1,02 & & 0,56 & \\
\hline & 0,29 & & 0,30 & & 1,35 & & 0,30 & & 0,29 & & 0,20 & \\
\hline \multirow[t]{2}{*}{$\begin{array}{l}\text { subiu de } \\
\text { classe }\end{array}$} & 0,69 & & 0,74 & & 0,70 & & 0,73 & & 0,75 & & 0,73 & \\
\hline & 0,19 & & 0,20 & & 0,19 & & 0,20 & & 0,20 & & 0,20 & \\
\hline \multirow[t]{2}{*}{$\begin{array}{l}\text { não ganha } \\
\text { Bolsa Família }\end{array}$} & 2,14 & & 0,80 & & 0,82 & & $0,470 *$ & & 0,80 & & 0,82 & \\
\hline & 1,04 & & 0,23 & & 0,24 & & 0,16 & & 0,24 & & 0,24 & \\
\hline \multirow[t]{2}{*}{$\begin{array}{l}\text { mais } \\
\text { informado }\end{array}$} & 1,13 & & 1,15 & & 1,20 & & 1,11 & & 1,15 & & 1,22 & \\
\hline & 0,30 & & 0,31 & & 0,33 & & 0,30 & & 0,31 & & 0,33 & \\
\hline \multirow[t]{2}{*}{$\begin{array}{l}\text { contatado na } \\
\text { campanha }\end{array}$} & 0,64 & & 0,59 & $*$ & 0,62 & & 0,63 & & 0,59 & $*$ & 0,62 & \\
\hline & 0,16 & & 0,15 & & 0,16 & & 0,16 & & 0,15 & & 0,16 & \\
\hline \multirow[t]{2}{*}{ mais ativista } & 1,09 & & 1,05 & & 0,96 & & 1,10 & & 1,08 & & 0,96 & \\
\hline & 0,30 & & 0,29 & & 0,26 & & 0,30 & & 0,30 & & 0,27 & \\
\hline $\begin{array}{l}\text { int. PT x } \\
\text { s/Bolsa }\end{array}$ & $\begin{array}{r}\mathbf{0 , 2 0} \\
0,13\end{array}$ & $*$ & & & & & & & & & & \\
\hline $\begin{array}{l}\text { int. PT } x \\
\text { escol. }\end{array}$ & & & $\begin{array}{r}\mathbf{0 , 4 2} \\
0,27\end{array}$ & & & & & & & & & \\
\hline
\end{tabular}


IDENTIFICAÇÃO PARTIDÁRIA E VOTO. AS DIFERENÇAS ENTRE PETISTAS E PEESSEDEBISTAS

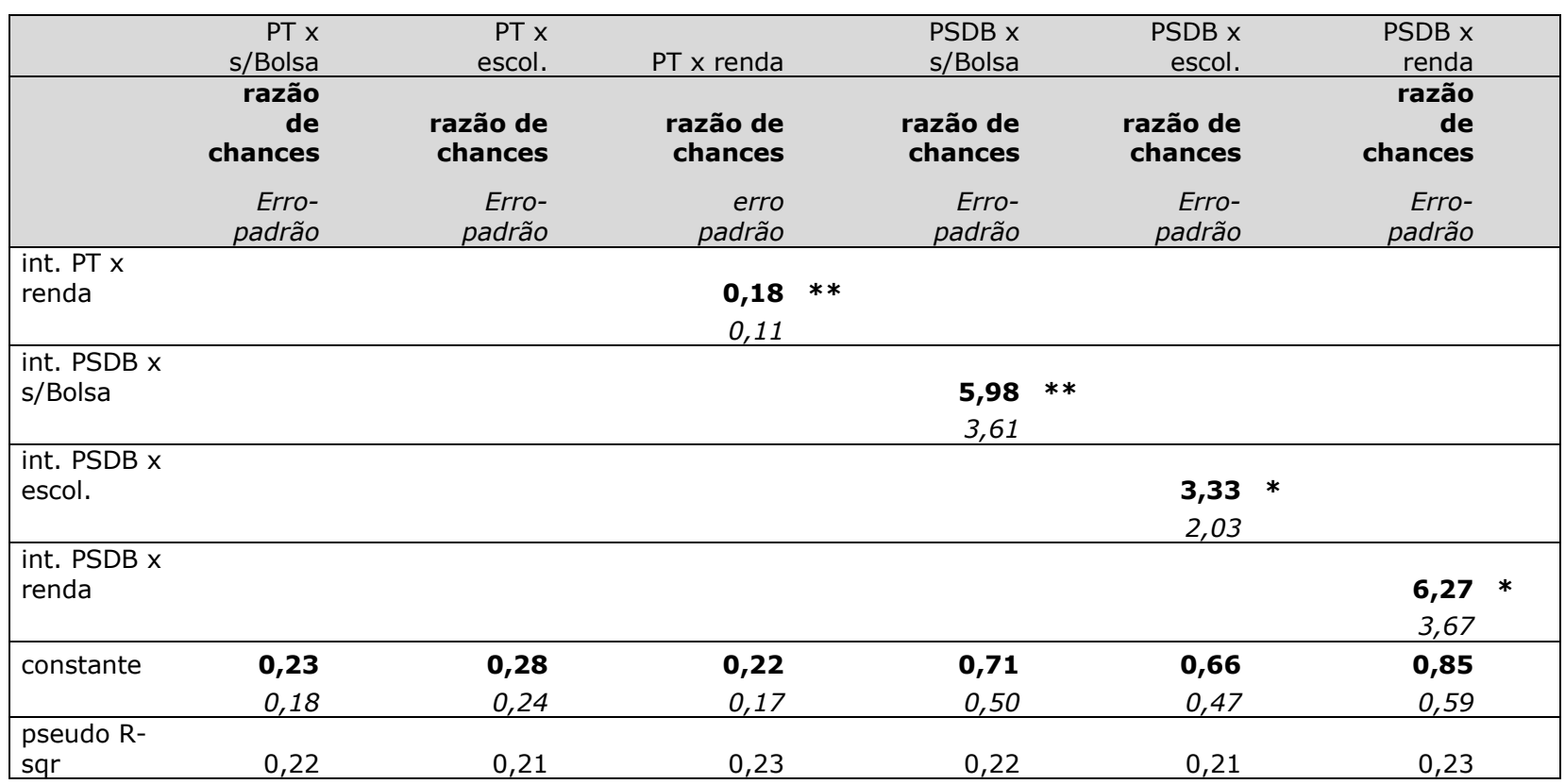

Fonte: Eseb 2014, tabulação própria.

$* \mathrm{p}<0.05, * * \mathrm{p}<0.01, * * * \mathrm{p}<0.001$.

Para completar essa análise nos debruçamos sobre o efeito da interação entre partidarismo e posição do cidadão na sociedade sobre a probabilidade de votar de forma coerente nos quatro cenários. Usamos para isso os gráficos sobre o efeito marginal dos dois principais fatores que incidem sobre a probabilidade de o cidadão votar de forma coerente. Diferentemente da Tabela 5, que inclui os partidários de todos os partidos, a análise nos gráficos do Quadro 1 compara somente partidários do PT e do PSDB, tomando como referência a sua coerência na votação presidencial. As variáveis de controle continuam as mesmas da Tabela 5. Os gráficos indicam, na dimensão vertical, a probabilidade de o cidadão votar de forma coerente, separadamente para petistas e peessedebistas. A probabilidade varia teoricamente de 0 a 1, no eixo y. Partidários com alta probabilidade de votar no candidato do seu partido estão na parte superior do gráfico enquanto os partidários que podem votar em candidatos de outro partido estão na parte inferior.

Nos três gráficos podemos verificar que os partidários do PT têm uma probabilidade maior de votar de forma coerente, em comparação com os partidários do PSDB. Esses mesmos gráficos identificam também o intervalo de confiança dessas probabilidades. Constatamos que a diferença entre petistas e peessedebistas é significativa nos grupos mais desfavorecidos (localizados à esquerda nos gráficos): os partidários do PT que recebem Bolsa Família, os que têm instrução inferior ao ensino médio completo e que ganham até dois SM são mais fiéis ao seu partido na hora de votar 
para presidente do que os partidários do PSDB. Entre os cidadãos que se encontram na situação oposta (localizados à direita nos gráficos), a diferença entre o grau de coerência de partidários dos dois partidos desaparece, ou melhor, ela deixa de ser estatisticamente significativa (os intervalos de confiança de $95 \%$ se sobrepõem).

Os gráficos também permitem interpretar de forma clara o efeito da interação do partidarismo com as variáveis referentes à Bolsa Família, instrução e renda, separadamente para cada partido. Fica evidente que o impacto da situação socioeconômica sobre a coerência dos petistas é inverso ao impacto sobre os partidários do PSDB. Os petistas que se encontram em situação socioeconômica mais precária são mais fiéis ao partido na hora de votar em presidente do que os petistas do outro grupo, aqueles que se encontram em situação menos desfavorável. A "banda" da probabilidade de voto coerente do PT cai levemente da esquerda para a direita. O intervalo de confiança indica que a diferença entre os dois grupos dentro do PT não é estatisticamente significativa (levando em conta $5 \%$ de chance de errar) ${ }^{7}$.

Entre os partidários do PSDB, os padrões de associação vão na direção oposta. Os partidários mais pobres são menos fiéis ao partido ao escolher seu candidato a presidente, comparados com os partidários em situação menos precária. A probabilidade de votação coerente dos peessedebistas aumenta de $60 \%$ para $80 \%$, aproximadamente, da esquerda para a direita nos três gráficos do mesmo quadro. Isso indica que a condição socioeconômica tem um impacto mais significativo sobre o partidarismo dos peessedebistas do que sobre os petistas. Por outro lado, levando em consideração o intervalo de confiança, verificamos que a diferença entre os dois grupos de peessedebistas não é estatisticamente significativa (levando em conta $5 \%$ de chance de errar) ${ }^{8}$.

\footnotetext{
${ }^{7}$ Isto pode ser relacionado ao baixo número de casos incluídos na análise $(n=567)$ que inclui somente partidários do PT e do PSDB.

8 Vide nota anterior.
} 
Quadro 1

Probabilidades de voto coerente dos partidários do PT e do PSDB, por situação socioeconômica

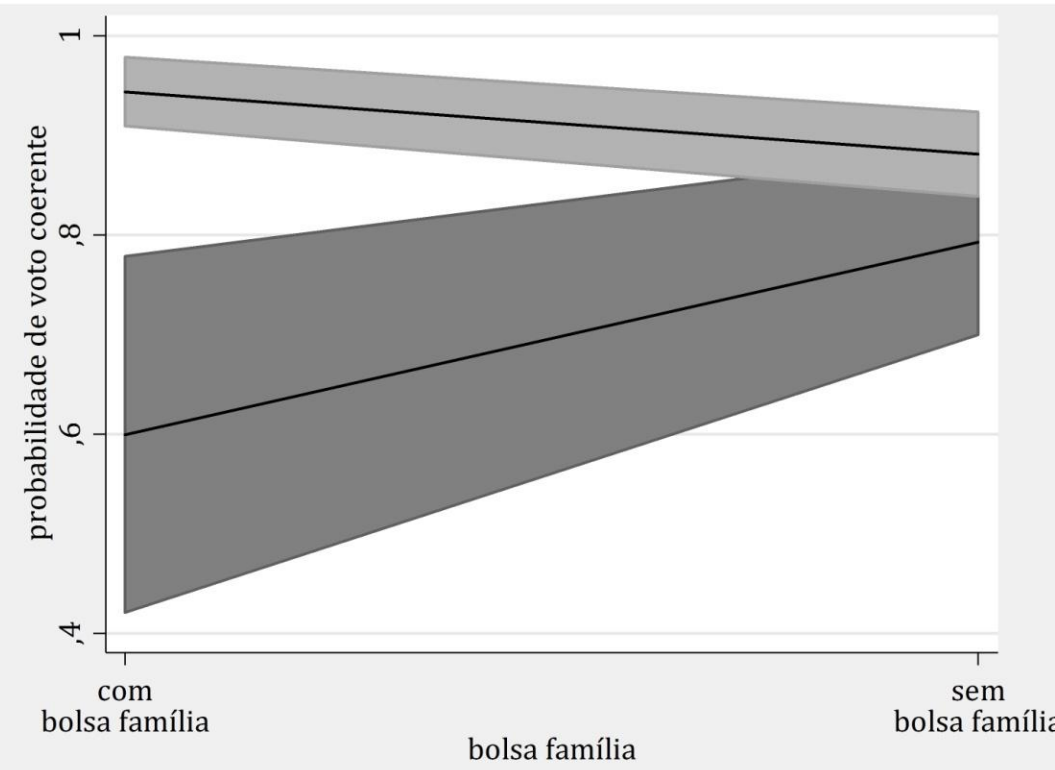

bolsa família

\begin{tabular}{|ll|}
\hline $\begin{array}{l}\text { partidários } \\
\text { do PSDB }\end{array}$ & $\begin{array}{l}\text { partidários } \\
\text { do PT }\end{array}$ \\
\hline
\end{tabular}

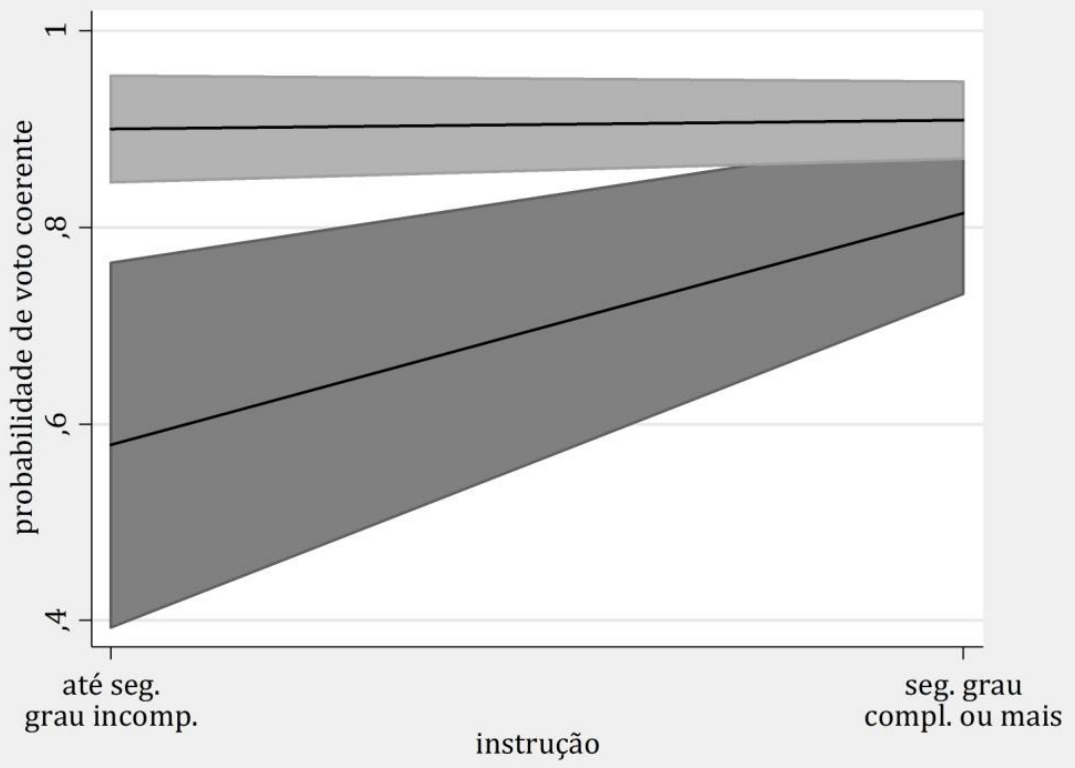

\begin{tabular}{ll}
$\begin{array}{l}\text { partidários } \\
\text { do PSDB }\end{array}$ & $\begin{array}{l}\text { partidários } \\
\text { do PT }\end{array}$ \\
\hline
\end{tabular}




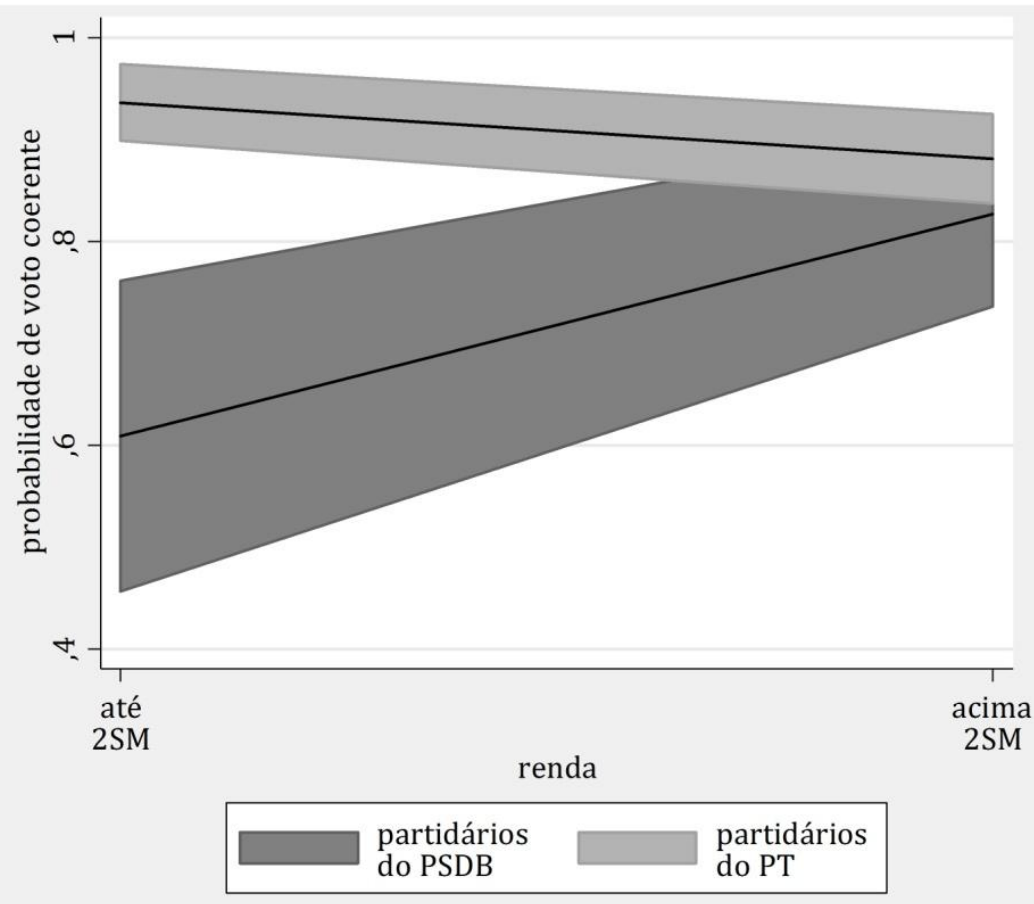

Fonte: Eseb 2014, elaboração própria.

Como assinalamos anteriormente, as três variáveis escolhidas representam três formas diferentes de captar a divisão básica da sociedade brasileira entre os estratos mais desfavorecidos e os menos desfavorecidos. A nossa hipótese é de que a tradução do sentimento partidarista em voto funciona de forma diferente para o primeiro e o segundo grupos. No caso dos petistas, a pertinência ao grupo mais desfavorecido tende a reforçar o efeito da identidade partidária. Entre os eleitores petistas de maior escolaridade, a lealdade é mais baixa e se traduz numa proporção menor de voto congruente, talvez porque esses eleitores sejam mais sensíveis à dissonância entre as propostas do partido e os interesses de seu grupo social. No primeiro grupo, podemos supor que a síndrome do torcedor de futebol entre em ação, produzindo altas taxas de lealdade e coerência. Mas, entre os petistas do segundo grupo, esse impacto é menos forte. As variáveis exploradas aqui dão apenas pistas para os mecanismos que estão por trás desses resultados. A variável da Bolsa Família fortalece o voto congruente, sugerindo que os eleitores podem se sentir na dependência do partido político que protege esse programa. O impacto moderador da variável escolaridade sugere que o efeito do torcedor incondicional seja enfraquecido na medida em que os cidadãos alcançam autonomia intelectual para absorver novas informações e participar do debate político. Mas as três variáveis captam clivagens muito próximas. Futuras pesquisas terão que avaliar em mais 
detalhe os mecanismos causais por trás desse efeito moderador da posição social sobre o partidarismo.

Já no caso dos eleitores identificados com o PSDB, a dissonância está entre aqueles que se encontram em situação de maior vulnerabilidade. Esses eleitores são menos atraídos para a candidatura de seu partido, em que pese sua identidade partidária. Por outro lado, pertencer aos grupos menos desfavorecidos parece reforçar a identidade desses eleitores e aumentar a probabilidade de um voto coerente.

\section{Dinâmicas cognitivas: identidade partidária e o entendimento das clivagens políticas}

Finalmente, a última dimensão em que a identificação partidária se mostrou significativa diz respeito à compreensão que os eleitores têm da clivagem central que organiza a competição eleitoral no Brasil. Ao longo da primeira década da Nova República a competição eleitoral no Brasil avançou de uma dinâmica policêntrica - que caracterizou as primeiras eleições presidenciais, quando os grandes partidos se enfrentavam com candidaturas próprias relativamente competitivas - para uma dinâmica bipolar (Lamounier e Meneguello, 1986; Carreirão e Kinzo, 2004; Melo, 2010). Desde pelo menos as eleições presidenciais de 1994, a competição eleitoral para a presidência da República convergiu para opor duas alianças partidárias relativamente estáveis: aquela organizada em torno das candidaturas apresentadas pelo PSDB e outra organizada em torno das candidaturas apresentadas pelo $\mathrm{PT}^{9}$.

O questionário utilizado pelo Eseb para as eleições de 2014 incorpora uma questão que, indiretamente, permite mensurar em que medida essa polarização também organiza a percepção que o eleitor tem sobre a competição eleitoral. Nessa questão solicitou-se ao eleitor que avaliasse, atribuindo uma nota de 0 a 10, o quanto ele gostava ou não de algumas lideranças expressivas da política nacional. Na lista apresentada aos eleitores estavam os nomes dos principais candidatos presentes na disputa para o cargo de presidente em 2014. Como se pode observar na Tabela 6, essa questão capta a visibilidade da disputa eleitoral. Não apenas as três candidaturas mais relevantes no primeiro turno - Marina, Dilma e Aécio - tiveram uma proporção muito maior de eleitores que souberam reconhecer e se dispuseram a avaliar essas personalidades, como também a dispersão dessas avaliações, medida pelo desvio-padrão ajustado pela média, é significativamente menor para essas três candidaturas, quando comparada com os resultados para os outros nomes.

\footnotetext{
${ }^{9}$ Ainda que, como bem alerta Carreirão (2014), essa estabilidade não se reproduz nas disputas eleitorais para outros níveis, notadamente para outros cargos majoritários, isto é, para os governos de estados e para as prefeituras.
} 


\section{Tabela 6 \\ Distribuição da avaliação dos candidatos à presidência da República}

\begin{tabular}{|c|c|c|c|c|c|}
\hline & $\begin{array}{c}\text { Gosta/ } \\
\text { Não gosta } \\
\text { Aécio Neves }\end{array}$ & $\begin{array}{c}\text { Gosta/ } \\
\text { Não gosta } \\
\text { Marina Silva }\end{array}$ & \begin{tabular}{|c|} 
Gosta/ \\
Não gosta \\
Dilma Rousseff
\end{tabular} & $\begin{array}{c}\text { Gosta/Não gosta } \\
\text { Eduardo Jorge }\end{array}$ & $\begin{array}{c}\text { Gosta/ } \\
\text { Não gosta } \\
\text { Luciana Genro }\end{array}$ \\
\hline Válidos & 2.304 & 2.258 & 2.378 & 1.343 & \begin{tabular}{|l|}
1.519 \\
\end{tabular} \\
\hline Casos & 202 & 248 & 128 & 1163 & 987 \\
\hline Média & 5,08 & 4,77 & 5,80 & 2,96 & 3,25 \\
\hline Desvio-padrão & 3,321 & 2,908 & 3,487 & 2,607 & 2,717 \\
\hline $\begin{array}{l}\text { Desvio- } \\
\text { Padrão/Média }\end{array}$ & 0,64 & 0,60 & 0,60 & 0,90 & 0,84 \\
\hline
\end{tabular}

Fonte: Eseb 2014, tabulação própria.

Dessa forma, é possível tomar como referência as respostas dadas pelos entrevistados a essa questão para mensurar indiretamente em que medida a polarização PSDB-PT é reconhecida pelo eleitor. Fizemos isso considerando simultaneamente a avaliação que ele dá para os candidatos desses dois partidos. A nova variável criada, que mensura a distância percebida pelo eleitor entre as duas candidaturas, é resultado da subtração do valor que o eleitor atribuiu a Dilma Rousseff (candidata do PT) do valor que o mesmo eleitor atribuiu a Aécio Neves (candidato do PSDB). Na Tabela 7 comparamos a distância que o eleitor percebe entre essas duas candidaturas, quando se controla a identidade partidária do eleitor.

\section{Tabela 7 \\ Distância percebida entre as candidaturas de Aécio Neves (PSDB) e Dilma Rousseff (PT), controlada pela identidade partidária}

\begin{tabular}{|l|c|c|c|}
\hline Identidade partidária & Mean & N & Std. Deviation \\
\hline PMDB & 1,8343 & 77 & 5,62109 \\
\hline PSDB & 5,6731 & 163 & 3,84561 \\
\hline PT & $-5,3638$ & 421 & 3,64749 \\
\hline Outros partidos &,- 0718 & 167 & 5,72592 \\
\hline Sem preferência &,- 1751 & 1455 & 4,87320 \\
\hline Total &,- 6394 & 2283 & 5,42213 \\
\hline
\end{tabular}

Fonte: Eseb 2014, tabulação própria.

Intervalo da distância: + 10 a - 10, em que valores próximos a zero indicam que o eleitor atribuiu notas semelhantes às duas candidaturas. Valores positivos indicam que a avaliação dada à candidatura de Aécio Neves é maior do que a dada a Dilma e vice-versa, valores negativos indicam que a avaliação de Dilma foi maior do a dada para Aécio Neves. Análise de variância: $F=189,251$, sig. 0,000, eta $^{2}=0,249$

Como se vê na Tabela 7, eleitores identificados com os dois partidos que estruturaram a polarização da competição eleitoral no nível presidencial reproduzem essa polarização na sua percepção da distância relativa das duas candidaturas: Os eleitores identificados com o PSDB avaliam positivamente o candidato de seu partido e, simultaneamente, avaliam negativamente a candidata do PT. Da mesma forma, eleitores 
identificados com o PT avaliam positivamente a candidata do seu partido e negativamente a candidatura do PSDB. Entretanto, essa distância é significativamente menor entre os eleitores identificados com o PMDB ou identificados com outros partidos e mesmo entre aqueles que não têm identificação partidária. Eleitores com esses perfis tenderam a atribuir notas semelhantes para as duas candidaturas e, portanto, expressam serem menos afetados pela polarização PT X PSDB, que vem organizando a competição eleitoral para a presidência da República no Brasil desde 1994.

Poder-se-ia, entretanto, objetar que o reconhecimento dessa polaridade tem escasso significado em termos da decisão de voto do eleitor. Entretanto, quando analisamos o impacto da percepção dessa polarização sobre as escolhas eleitorais para o nível da presidência entre as eleições de 2010 e 2014, verificamos que a percepção dessa polarização é central para sustentar a congruência dessas escolhas, tanto entre os dois turnos de uma mesma eleição como entre anos eleitorais (Tabela 8).

Para reconstituir a retrospectiva do voto, consideramos as informações que o entrevistado deu sobre o seu voto nos dois turnos das eleições presidenciais de 2014 e de 2010. Essas informações foram recodificadas para identificar se, em cada eleição, o entrevistado votou no candidato do PT, no candidato do PSDB ou em candidatos de outros partidos (primeiro turno), ou ainda votou em branco ou anulou o voto. As informações dadas por cada eleitor para as duas eleições foram pareadas e os resultados nos permitem identificar cinco diferentes perfis de decisão eleitoral: eleitores que, nas quatro chances de exprimir seu voto, o fizeram votando sempre em candidaturas do PSDB ou sempre em candidaturas do PT; eleitores que em uma dessas eleições votaram no PSDB e em outras num outro partido (ou deram voto nulo ou em branco), mas nunca cruzaram a linha da polarização PT X PSDB; eleitores que em uma das eleições votaram no PT e, em outras, votaram em outros partidos (ou deram voto nulo ou em branco), mas que, ainda assim, também não cruzaram a linha de competição que separa PT e PSDB, e, finalmente, eleitores cujas opções eleitorais, seja entre turnos da mesma eleição ou entre diferentes eleições, cruzaram a linha da polarização: isto é, declararam que em alguma(s) oportunidade(s) votaram no PT e, em outra(s), no PSDB. A Tabela 8 compara a distância média das avaliações que os eleitores deram para as candidaturas Dilma e Aécio, considerando cada um dos perfis de decisão eleitoral descritos acima. 


\section{Tabela 8}

Distância entre as candidaturas PSDB-PT e retrospectiva do voto

\begin{tabular}{|c|c|c|c|}
\hline \multirow[b]{2}{*}{$\begin{array}{l}\text { Retrospectiva de voto para a } \\
\text { presidência, } 2014 \text { e } 2010 \text { (dois } \\
\text { turnos) }\end{array}$} & \multicolumn{3}{|c|}{$\begin{array}{l}\text { Distância entre a nota dada ao candidato do PSDB e } \\
\text { a nota dada à candidata do PT, } 2014 \text { (positivo: nota } \\
\text { maior para o PSDB, negativo, nota maior para o PT) }\end{array}$} \\
\hline & Mean & $\mathbf{N}$ & Std. Deviation \\
\hline Só votou PSDB & 5,8399 & 213 & 3,35869 \\
\hline PSDB e outros, exceto PT & 4,8035 & 126 & 3,62158 \\
\hline PSDB e PT &, 5978 & 450 & 4,48065 \\
\hline PT e outros, exceto PSDB & $-2,5305$ & 63 & 3,35920 \\
\hline Só votou PT & $-4,8437$ & 659 & 3,46259 \\
\hline Total &,- 8180 & 1510 & 5,56857 \\
\hline
\end{tabular}

Fonte: Eseb 2014, tabulação própria.

Teste Anova: $f=438,03$, sig. 0,000, eta $^{2}=0,538$.

$\mathrm{Na}$ Tabela 8, vemos que a associação entre essas duas dimensões é impressionante. O reconhecimento da polarização - expresso na distância que o eleitor estabelece para sua avaliação das duas candidaturas na eleição de 2014 - está forte e significativamente associado aos diferentes perfis de escolhas eleitorais que se sustentam ao longo do tempo. A análise de variância (Anova) mostra que nada menos que $54 \%$ da variância observada para a variável "distância da avaliação" é explicada pelo padrão de escolha informado por esses eleitores.

Eleitores que favoreceram em sua avaliação o candidato do PSDB e, simultaneamente, avaliaram negativamente a candidatura do PT são também aqueles que sustentam o voto nesse partido ao longo do tempo. Da mesma forma, eleitores que votaram no PSDB e em outros partidos, mas não cruzaram a linha de polarização que distingue PT e PSDB, tenderam a apresentar o mesmo padrão polarizado de avaliação das duas candidaturas. De outro lado, eleitores que declararam sempre ter votado no PT atribuíram uma baixa avaliação ao candidato do PSDB e, simultaneamente, expressaram uma forte apreciação pela candidatura do polo oposto, PT. Esse padrão se repete para aqueles que votaram no PT e em outros partidos, mas também nunca cruzaram a distância que separa PSDB e PT. Finalmente, os eleitores que declararam opções eleitorais cruzadas, ora votando no candidato do PT, ora votando no candidato do PSDB, tenderam a dar avaliações próximas aos dois candidatos apresentados por esses partidos nas eleições de 2014. É preciso recordar que a construção desses perfis de padrão de votação leva em conta o voto declarado pelo eleitor nos dois turnos de eleição em 2010 e 2014. Assim, esses resultados são congruentes com a hipótese de que a identidade partidária tem reflexos sobre o entendimento que o eleitor tem da competição que organiza o espaço eleitoral. O que, por sua vez, parece ter reflexos na sustentação da escolha eleitoral ao longo do tempo. 


\section{Conclusão}

Este artigo analisou os impactos da identificação partidária nas eleições de 2014, buscando avaliar seus efeitos nas atitudes e valores sustentados pelos eleitores e os seus reflexos sobre a decisão de voto. Embora a proporção de eleitores simpatizantes de partidos venha experimentando quedas sucessivas desde pelo menos o final dos anos 1990, ainda assim consideramos relevante entender o que está por trás da decisão de um entrevistado quando responde positivamente ao ser indagado se ele gosta de algum partido.

Sendo assim, avaliamos se a identificação partidária ajuda a entender o processo eleitoral no Brasil a partir de duas perspectivas. Em primeiro lugar, buscamos avaliar em que medida essa informação permite entender o voto e, em segundo lugar, qual a relação entre a identidade partidária e as atitudes e opiniões expressas pelos eleitores. Para responder à primeira das duas questões, analisamos a extensão do partidarismo no Brasil e suas consequências para as escolhas eleitorais do pleito de 2014. Diferentemente de outros estudos anteriores, analisamos o impacto do partidarismo sobre todas as escolhas eleitorais para os cinco cargos em disputa. Nessa perspectiva, os resultados deste artigo mostram que, considerando o impacto da identificação partidária sobre a escolha eleitoral, o partidarismo foi mais importante nas eleições para a presidência da República e, nesse nível, teve um efeito mais relevante entre simpatizantes do PT e do PSDB. Na eleição para esse cargo, os simpatizantes do PT tiveram 38,3 vezes mais chances de votar na candidata do seu partido em comparação com os outros partidos. Os simpatizantes do PSDB tiveram 10,7 vezes mais chance de votar no seu candidato, quando comparados com eleitores identificados com outros partidos.

Nossa análise mostrou também que as bases eleitorais de diferentes partidos apresentam padrões diferentes de fidelidade quando se consideram os diferentes cargos em disputa nas eleições: enquanto entre os eleitores do PT a probabilidade de voto congruente é maior para a eleição presidencial e declina para os outros níveis de eleição, no caso do PSDB, o padrão é inverso: a probabilidade de voto congruente é maior para as eleições subnacionais e menor para a eleição presidencial. No caso dos simpatizantes do PMDB não houve nenhuma associação significativa entre a identidade partidária e a probabilidade de um voto coerente, quando comparado com os eleitores de outros partidos. Nas eleições para deputado federal e estadual, o fenômeno do partidarismo tem impacto reduzido.

Este artigo também explorou a hipótese de que a identificação partidária possa funcionar como um fator de mediação entre o eleitor e o mundo da política. Aqui a ideia é que a identificação não atua da mesma forma para os diferentes grupos. Enquanto para alguns estratos sociais a identificação é um atalho informacional importante para o voto, para outros ela é apenas uma entre várias fontes alternativas de informação e avaliação das opções políticas atuais. Essa hipótese supõe que a identidade partidária seja um fator 
mais poderoso para os eleitores com menos recursos cognitivos, e mais fraco, porque compete com outras fontes de informação, entre os eleitores com mais recursos cognitivos.

A nossa análise aponta um resultado paradoxal: dependendo de qual partido tomamos para estudo, os resultados se aproximam do modelo proposto acima ou não. Assim, enquanto entre os eleitores petistas os menos escolarizados foram mais fiéis ao partido, quando comparados com eleitores identificados com outros partidos, essa congruência foi menor entre os petistas mais escolarizados. Mas o padrão observado entre os eleitores peessedebistas é o inverso: a proporção de votos congruentes é maior entre os eleitores mais escolarizados e menor entre os eleitores menos escolarizados.

A última dimensão analisada neste artigo é o impacto da identificação partidária na compreensão que os eleitores têm da oposição que organiza a competição eleitoral no Brasil. Os resultados de nosso estudo mostram que os eleitores identificados com os dois partidos que estruturam a polarização da competição eleitoral no nível presidencial reproduzem essa polarização na sua percepção da distância relativa das candidaturas apresentadas por esses partidos na eleição presidencial de 2014. Já entre os identificados com o PMDB, com outros partidos e entre aqueles que não têm identificação partidária, a distância relativa entre as duas candidaturas é menor. Eleitores com esses perfis tenderam a atribuir notas semelhantes para as duas candidaturas, e, portanto, revelam menor sensibilidade para a principal polarização que vem organizando a competição eleitoral para a presidência da República no Brasil desde 1994. Por outro lado, essa dimensão - distância relativa entre as candidaturas - mostrou-se fortemente relacionada com o padrão de votação expresso pelos eleitores, quando consideram simultaneamente os votos dados nos dois turnos das eleições presidenciais de 2010 e 2014.

Portanto, os resultados deste artigo mostram que a identificação partidária é relevante no contexto brasileiro em diversas dimensões. Ela continua tendo um impacto diferenciado para a decisão de voto e está fortemente associada à compreensão que esse eleitor tem das dinâmicas de competição política e eleitoral. Em que pese o declínio da identidade partidária no eleitorado brasileiro, a simpatia expressa em relação a um dos partidos continua tendo impacto relevante e significativo na percepção que o eleitor tem das dinâmicas da competição partidária e na sua decisão eleitoral.

Bruno Wilhelm Speck - Departamento de Ciência Política, Faculdade de Filosofia, Letras e Ciências Humanas, Universidade de São Paulo. E-mail: <bws@usp.br>.

Elizabeth Balbachevsky - Departamento de Ciência Política, Faculdade de Filosofia, Letras e Ciências Humanas, Universidade de São Paulo. E-mail: <balbasky@usp.br>. 


\section{Referências bibliográficas}

ALMOND, G. A.; VERBA, S. The civic culture: political attitudes and democracy in five nations, an analytic study. Boston: Little Brown, 1965.

ANDERSEN, K. Generation, partisan shift and realigment: a glance back to the New Deal. In: NIE, N. H.; VERBA, S.; PETROCIK, J. The changing American voter (enlarged edition). Cambridge, MS: Harvard University Press, pp.74-95, 1979.

BAKER, A.; Ames, B.; RenNó, L. R. "Social context and campaign volatility in new democracies: networks and neighborhoods in Brazil's 2002 elections". American Journal of Political Science, vol. 50, no 2, p. 382-399, Summer, 2006.

BAKER, A., et al. "The dynamics of partisan identification when party brands change: the case of the Workers Party in Brazil". The Journal of Politics, vol. 78, no 1, p. 197-213, Spring, 2015.

BALBACHEVSKY, E. "Identidade partidária e instituições políticas no Brasil". Lua Nova: Revista de Cultura e Política, vol. 26, p. 133-165, jan. 1992.

BARnes, S. H.; MCDonough, P.; PinA, A. L. "The development of partisanship in new democracies: the case of Spain". American Journal of Political Science, vol. 29, no 4, p. 695-720, Winter, 1985.

Braga, M. S. S.; PImentel JR., J. "Os partidos políticos brasileiros realmente não importam?". Opinião Pública, vol. 17, no 2, p. 271-303, abr. 2011.

Campbell, A., et al. The American voter. Chicago: University of Chicago Press, 1960.

CARREIRÃO, Y. S. "O sistema partidário brasileiro: um debate com a literatura recente". Revista Brasileira de Ciência Política, no 14, p. 255-295, 2014.

CARREIRÃo, Y. S.; Kinzo, M. D. G. "Partidos políticos, preferência partidária e decisão eleitoral no Brasil (1989/2002)". Dados, vol. 47, n 1, p. 131-167, jan. 2004.

DALTON, R. J.; MCAllister, I.; WATtenberg, M. P. "Democracia e identificação partidária nas sociedades industriais avançadas". Análise Social, vol. 38, no 167, p. 295-320, 2003.

Downs, A. An economic theory of democracy. New York: Harper, 1957.

FIORINA, M. P. "An outline for a model of party choice". American Journal of Political Science, vol. 21, no 3, p. 601-625, Fall, 1977.

KInzo, M. D. G. "Partidos, eleições e democracia no Brasil pós-1985". Revista Brasileira de Ciências Sociais, vol. 19, no 54, p. 23-40, fev. 2004.

KInZo, M. D. G. "Os partidos no eleitorado: percepções públicas e laços partidários no Brasil". Revista Brasileira de Ciências Sociais, vol. 20, no 57, p. 65-81, fev. 2005.

LAmounieR, B. O voto em São Paulo, 1970-1978. In: LAmounieR, B. (org.). Voto de desconfiança em São Paulo. São Paulo: Vozes/Cebrap, p. 15-80, 1980.

LAmounier, B.; Meneguello, R. Partidos políticos e consolidação democrática: o caso brasileiro. São Paulo: Brasiliense, 1986.

LIPSET, S. M.; ROKKAN, S. Party systems and voter alignments: cross-national perspectives. New York: Free Press, 1967. 
Melo, C. R. "Eleições presidenciais, jogos aninhados e sistema partidário no Brasil". Revista Brasileira de Ciência Política, vol. 0, no 4, p. 13-41, 2010.

Melo, C. R.; CÂMARA, R. "Estrutura da competição pela Presidência e consolidação do sistema partidário no Brasil". Dados, vol. 55, no 1, 71-117, fev. 2012.

Nicolau, J. "An analysis of the 2002 presidential elections using logistic regression". Brazilian Political Science Review, vol. 1, no 1, p. 125-135, fev. 2007.

Paiva, D.; Braga, M. S. S.; Pimentel JR., J. T. P. "Eleitorado e partidos políticos no Brasil". Opinião Pública, vol. 13, no 2, p. 388-408, abr. 2007.

PAIVA, D.; TAROuco, G. S. "Voto e identificação partidária: os partidos brasileiros e a preferência dos eleitores". Opinião Pública, vol. 17, no 2, p. 426-451, abr. 2011.

PEREIRA, F. B. Why are there more partisans in some countries than in others? (Americas Barometer No 71). Vanderbilt University, 2012. Disponível em:

<http://www.vanderbilt.edu/lapop/insights/IO871en.pdf>. Acesso em: 8 mar. 2016.

. "A estabilidade e a efetividade da preferência partidária no Brasil". Revista Brasileira de Ciência Política, no 13, p. 213-244, jan.-abr., 2014.

Pimentel JR., J. Disposições afetivas e laços partidários no Brasil. In: Kinzo, M. D. G.; BRAGA, M. S. S. (orgs.). Eleitores e representação partidária no Brasil. São Paulo: Humanitas, p. 81-113, 2007.

Plasser, F.; PlASSER, G. Global political campaigning. Westport, CT: Praeger, 2002. Disponível em: <https://books.google.com.br/books/about/Global_Political_Campaigning.html?hl=ptBR\&id=ILAEM8SZfZcC >. Acesso em: 8 mar. 2016

REIS, F. W. "Identidade política e a teoria da escolha racional". Revista Brasileira de Ciências Sociais, vol. 3, no 6, p. 26-38, 1988.

RENNó, L. R. "Validade e confiabilidade das medidas de confiança interpessoal: o barômetro das Américas". Dados, vol. 54, no 3, 391-428, 2011.

Rennó, L. R., et al. Legitimidade e qualidade da democracia no Brasil: uma visão da cidadania. São Paulo: Intermeios, 2011.

Samuels, D. "As bases do petismo". Opinião Pública, vol. 10, no 2, p. 221-241, abr., 2004.

2008.

. "A evolução do petismo (2002-2008)". Opinião Pública, vol. 14, no 2, p. 302-318, abr.

SAMUels, D.; Zucco, C. "Lulismo, petismo, and the future of Brazilian politics". Journal of Politics in Latin America, vol. 6, no 3, p. 129-158, Fall, 2014 a.

. "The power of partisanship in Brazil: evidence from survey experiments". American Journal of Political Science, vol. 58, no 1, p. 212-225, Spring, 2014b.

Singer, A. "A segunda alma do partido dos trabalhadores". Novos Estudos Cebrap, no 88, p. 89-111, 2010.

SPECK, B. W.; BRAGA, M. S. S.; COSTA, V. "Estudo exploratório sobre filiação e identificação partidária no Brasil". Revista de Sociologia e Política, vol. 23, no 56, p. 125-148, dez. 2015. 
VEIGA, L. F. "Os partidos brasileiros na perspectiva dos eleitores: mudanças e continuidades na identificação partidária e na avaliação das principais legendas após 2002". Opinião Pública, vol. 13, no 2, p. 340-365, abr. 2007.

$\frac{}{2011 .}$. "O partidarismo no Brasil (2002/2010)". Opinião Pública, vol. 17, no 2, p. 400-425., abr.

VENTURI, G. "PT 30 anos: crescimento e mudanças na preferência partidária". Revista Perseu, no 5, 196-214, jun. 2010.

\title{
Resumo
}

Identificação partidária e voto. As diferenças entre petistas e peessedebistas

Neste artigo analisamos o impacto da identificação partidária sobre o comportamento eleitoral no Brasil. Usamos dados do Eseb realizado em 2014 com uma amostra representativa de eleitores de âmbito nacional. Em relação aos outros trabalhos a respeito do impacto da identificação sobre o voto, inovamos em dois aspectos. Primeiro, não nos limitamos à análise do voto para presidente, mas incluímos o voto para todos os cargos em disputa em 2014. Segundo, mostramos que a identificação partidária não atua da mesma forma sobre todos os eleitores identificados com um mesmo partido. Mostramos que partidários do PT são mais coerentes no seu voto para presidente quando têm maior nível de instrução, ao passo que os partidários do PSDB são mais fiéis na mesma questão quando têm baixa instrução. Da mesma forma, petistas são fiéis na hora de votar no presidente, enquanto os peessedebistas votam com seu partido na hora de escolher governadores e senadores. Finalmente, nossa análise identificou um padrão complexo entre as variáveis educação, aqui tomada como proxy dos recursos cognitivos do eleitor, identidade partidária e decisão de voto. Essa última contribuição leva a discussão sobre a identificação partidária no Brasil para além das questões sobre sua presença ou ausência no eleitorado, e sua relevância para entender a decisão de voto, que são as abordagens dominantes na literatura que trata do tema.

Palavras-chaves: eleições brasileiras de 2014; identificação partidária; voto para presidente, governador, senador, deputado federal e estadual

\begin{abstract}
Party identification and the vote: the differences between supporters of the PT and supporters of the PSDB

In this article, we analyze the impact of party identification on voting behavior in Brazil. We use data from the ESEB conducted in 2014, with a nationally representative sample of voters. In relation to other works on the impact of identification on the vote, we innovate in two areas. First, we do not limit our analysis to the vote for president; rather, we analyze vote for all offices in dispute in 2014. Second, we show that party identification does not work in the same way for all voters who identify with the same party. We have shown that supporters of the PT with higher levels of education are more coherent in their vote for President, while supporters of the PSDB with lower levels of education show more partisan loyalty in their vote. In the same way, while petistas are loyal to their party when it comes to voting for the President, peessedebistas vote with their party when it comes to choosing Governors and Senators. Finally, our analysis has identified a complex pattern of relationships between education-used here as a proxy for voters' cognitive resources-party identification, and vote choice. This last contribution promotes a discussion about the meaning of party identification in Brazil, one that goes well beyond the usual issues of its presence or absence among the electorate and its relevance to our understanding of vote choice, which have dominated the literature dealing with this topic in Brazil.
\end{abstract}

Keywords: 2014 Brazilian elections; party identification; vote for president; vote for governors; vote for the Senate; vote for federal and state deputies 


\section{Resumen}

Partidismo y voto. Las diferencias entre los partidarios del PT y los partidarios del PSDB

Este artículo analiza el impacto de la identificación partidaria sobre el comportamiento electoral en Brasil. Los datos del Eseb de 2014 son sobre una muestra representativa de los electores brasileños. El análisis no se limitó al voto para Presidente, sino que incluyó a los votos para todos los cargos de elección popular en el 2014. El análisis muestra que la identificación con el partido no influencia de la misma manera a todos los electores identificados con el mismo partido. Los Autores muestran que aquellos identificados con el PT son más coherentes en su voto para Presidente cuando tienen mayor nivel de educación, mientras los electores identificados con PSDB son más fieles, en esta situación, cuando tienen un nivel menor de educación. Asimismo, los petistas son fieles cuando votan para Presidente, mientras los peesedebistas votan por su partido en las elecciones para Gobernador y Senador. Por último, nuestro análisis ha encontrado un complejo patrón de conexiones entre la variable de educación - empleada como proxy de recursos cognitivos del elector - y las variables de identificación con el partido y de decisión del voto. Esta última contribución plantea la discusión sobre la identificación con el partido más allá de las cuestiones sobre si esta identificación de hecho existe y si ella es pertinente, de acuerdo con el enfoque predominante en la literatura sobre este tema.

Palabras clave: Brasil, elecciones generales de 2014, identificación partidaria, voto para presidente, voto para gobernador, voto para senador, voto para representante federal y provincial

\section{Résumé}

Identification partisane et vote. Les différences entre les électeurs du PT et du PSDB

Nous analysons dans cet article l'impact de I'identification partisane sur le comportement électoral au Brésil. Nous utilisons les données de I'Eseb réalisée en 2014 auprès d'un échantillon représentatif d'électeurs à l'échelle nationale. Par rapport aux autres études sur l'impact de I'identification sur le vote, nous innovons dans deux aspects. Premièrement, nous ne nous limitons pas à I'analyse du vote pour le président, nous incluons le vote pour tous les mandats à pourvoir en 2014. Deuxièmement, nous montrons que I'identification partisane $n$ 'agit pas de la même façon sur tous les électeurs identifiés auprès d'un même parti. Nous montrons que les personnes identifiées auprès du PT sont proportionnellement plus cohérentes au moment de voter pour le président que leur niveau scolaire est élevé ; alors que les personnes identifiées auprès du PSDB sont plus fidèles, dans le même domaine, quand elles ont un faible niveau scolaire. De même, les électeurs du PT sont fidèles quand il s'agit de voter pour le président, alors que ceux du PSDB votent avec leur parti que il faut choisir des gouverneurs et des sénateurs. Finalement, notre analyse a identifié un modèle complexe entre la variable d'éducation, ici considérée comme proxy des ressources cognitives de I'électeur, et les variables d'identification auprès du parti et de décision de vote. Cette dernière contribution projette la discussion sur l'identification partisane au Brésil au-delà des questions sur sa présence ou son absence au sein de l'électorat, et de son importance pour comprendre la décision de vote, qui sont les approches qui dominent dans la littérature traitant du sujet.

Mots-clés: Brésil; élections de 2014; identification partisane; vote pour le président, le gouverneur, le sénateur, le député fédéral et d'état

Artigo submetido à publicação em março de 2016. Versão final aprovada em novembro de 2016. 